\title{
Link between local scale BC emissions in the Indo-Gangetic Plains and large scale atmospheric solar absorption
}

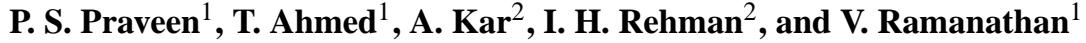 \\ ${ }^{1}$ Center for Clouds, Chemistry and Climate, Scripps Institution of Oceanography, University of California, San Diego, \\ 9500 Gilman Drive, MC 0221, La Jolla, CA 92093-0221, USA \\ ${ }^{2}$ The Energy and Resources Institute, Darbari Seth Block, IHC Complex, Lodhi Road, New Delhi, 110003, India
}

Correspondence to: V. Ramanathan (vramanathan@ucsd.edu)

Received: 7 June 2011 - Published in Atmos. Chem. Phys. Discuss.: 28 July 2011

Revised: 9 December 2011 - Accepted: 5 January 2012 - Published: 30 January 2012

\begin{abstract}
Project Surya has documented indoor and outdoor concentrations of black carbon (BC) from traditional biomass burning cook stoves in a rural village located in the Indo-Gangetic Plains (IGP) region of N. India from November 2009-September 2010. In this paper, we systematically document the link between local scale aerosol properties and column averaged regional aerosol optical properties and atmospheric radiative forcing. We document observations from the first phase of Project Surya and estimate the source dependent (biomass and fossil fuels) aerosol optical properties from local to regional scale. Data were collected using surface based observations of $\mathrm{BC}$, organic carbon (OC), aerosol light absorption, scattering coefficient at the Surya village (SVI_1) located in IGP region and integrated with satellite and AERONET observations at the regional scale (IGP). The daily mean BC concentrations at SVI_1 showed a large increase of $\mathrm{BC}$ during the dry season (December to February) with values reaching $35 \mu \mathrm{g} \mathrm{m}^{-3}$. Space based LIDAR data revealed how the biomass smoke was trapped within the first kilometer during the dry season and extended to above $5 \mathrm{~km}$ during the pre-monsoon season. As a result, during the dry season, the variance in the daily mean single scattering albedo (SSA), the ratio of scattering to extinction coefficient, and column aerosol optical properties at the local IGP site correlated (with slopes in the range of 0.85 to 1.06 and $R^{2}>0.4$ ) well with the "IGP_AERONET" (mean of six AERONET sites). The statistically significant correlation suggested that in-situ observations can be used to derive spatial mean forcing, at least for the dry season. The atmospheric forcing due to $\mathrm{BC}$ and $\mathrm{OC}$ exceeded $20 \mathrm{Wm}^{-2}$ during all months from November to May, supporting the deduction that elimination of cook stove smoke emissions through
\end{abstract}

clean cooking technologies will likely have a major positive impact not only on human health but also on regional climate.

\section{Introduction}

Roughly half of the world's population relies on solid fuels (wood, animal dung, crop residues and coal) for daily household energy needs. Cooking with these fuels results in the emission of a significant amount of smoke (comprised mainly of black carbon and the condensed fraction of semivolatile organics) due to incomplete combustion. For the most part, cooking is done in the kitchen microenvironment with poor ventilation, which leads to an extensive build-up of smoke; this in turn results in exposure to high levels of particulate matter which causes adverse health effects (Sauvain et al., 2006; Smith et al., 2004; Schwarze et al., 2006). This indoor smoke escapes outdoors and leads to atmospheric brown clouds (ABCs) (Ramanathan et al., 2001a).

Black carbon (BC), a major component of smoke, strongly absorbs sunlight in the atmosphere and is considered to be the second largest contributor to global warming after $\mathrm{CO}_{2}$ (Ramanathan and Carmichael, 2008; Jacobson, 2010). BC significantly impacts global climate as well as regional climate by perturbing the monsoon circulation and contributing to the retreat of mountain glaciers (Ramanathan et al., 2001a; Lau et al., 2008; Menon et al., 2002, 2010; Flanner et al., 2009; Pettus, 2009). Because of its positive atmospheric radiative forcing (i.e. warming) and relatively short residence time in the atmosphere (few days to weeks) compared to $\mathrm{CO}_{2}$ (lifetime of decades to centuries), reducing BC emissions 
presents unique opportunities for delaying climate change (Ramanathan and Wallack, 2008; Molina et al., 2009; Ramanathan and $\mathrm{Xu}, 2010)$. Organic carbon (OC), co-emitted along with $\mathrm{BC}$, was previously known to have negligible solar absorption and thus assumed to have only a cooling effect (Andreae and Gelencser, 2006). However, studies have shown that some OC fractions (referred to as brown carbon) emitted mostly during biomass burning show strong wavelength dependence of absorption in the ultraviolet and visible region $(<600 \mathrm{~nm})$ (Kirchstetter et al., 2004), thus adding to positive atmospheric radiative forcing.

Biofuel combustion is the predominant source of BC emissions $\left(\mathrm{Tg} \mathrm{yr}^{-1}\right)$ over Africa (72\%) and South Asia (68\%) (Reddy and Boucher, 2007). Over India, BC emissions $\left(\mathrm{Gg} \mathrm{yr}^{-1}\right)$ from fossil fuel, open burning, and biofuel combustion contribute around $25 \%, 33 \%$, and $42 \%$, respectively (Venkatraman et al., 2005). Model simulation has shown that replacing traditional methods of cooking (i.e. burning biomass fuel in a mud stove) with improved cook stoves may significantly reduce atmospheric BC burden over South and East Asia (Ramanathan and Carmichael, 2008). The Indo-Gangetic Plain (IGP), situated along the southern edge of the Himalayan region and spanning across the North-Eastern parts of India, is one of the most densely populated regions on the planet. It is characterized by large anthropogenic emissions from rural households, thermal power plants and industries, causing a widespread layer of ABCs over the region (Ramanathan and Ramana, 2005), as revealed by MODIS aerosol optical depth for the IGP region (Fig. 1). Project Surya is the first field study designed to examine the potential of mitigating biomass $\mathrm{BC}$ emissions for slowing down global warming and for reducing negative health effects (Ramanathan and Balakrishnan, 2007). The first (or pilot) phase of Project Surya was started in October 2009 in a rural village located in the IGP region of Northern India. The first phase observations were devoted to baseline measurements of $\mathrm{BC}$ concentration and aerosol optical properties from both indoors and outdoors.

This is the third in a series of four papers on the first phase study. The first paper (Ramanathan et al., 2011) dealt with a cell-phone based BC monitoring system for large scale (e.g. 100-300 households) measurements. The second paper (Rehman et al., 2011) explored the link between indoor and outdoor BC concentration. The fourth paper (Kar et al., 2011) investigated different commercially available improved cook stoves for cutting down $\mathrm{BC}$ emissions. This study documents the baseline $\mathrm{BC}$ measurements on diurnal, daily and seasonal time scales and examines the source dependent aerosol light absorption characteristics. One of the main goals of Project Surya is to document the impact of $\mathrm{BC}$ mitigation on regional climate. This study also integrates the surface data collected in the village with other groundbased network and satellite observations in order to probe the link between local-scale emissions and regional-scale atmospheric BC solar absorption.
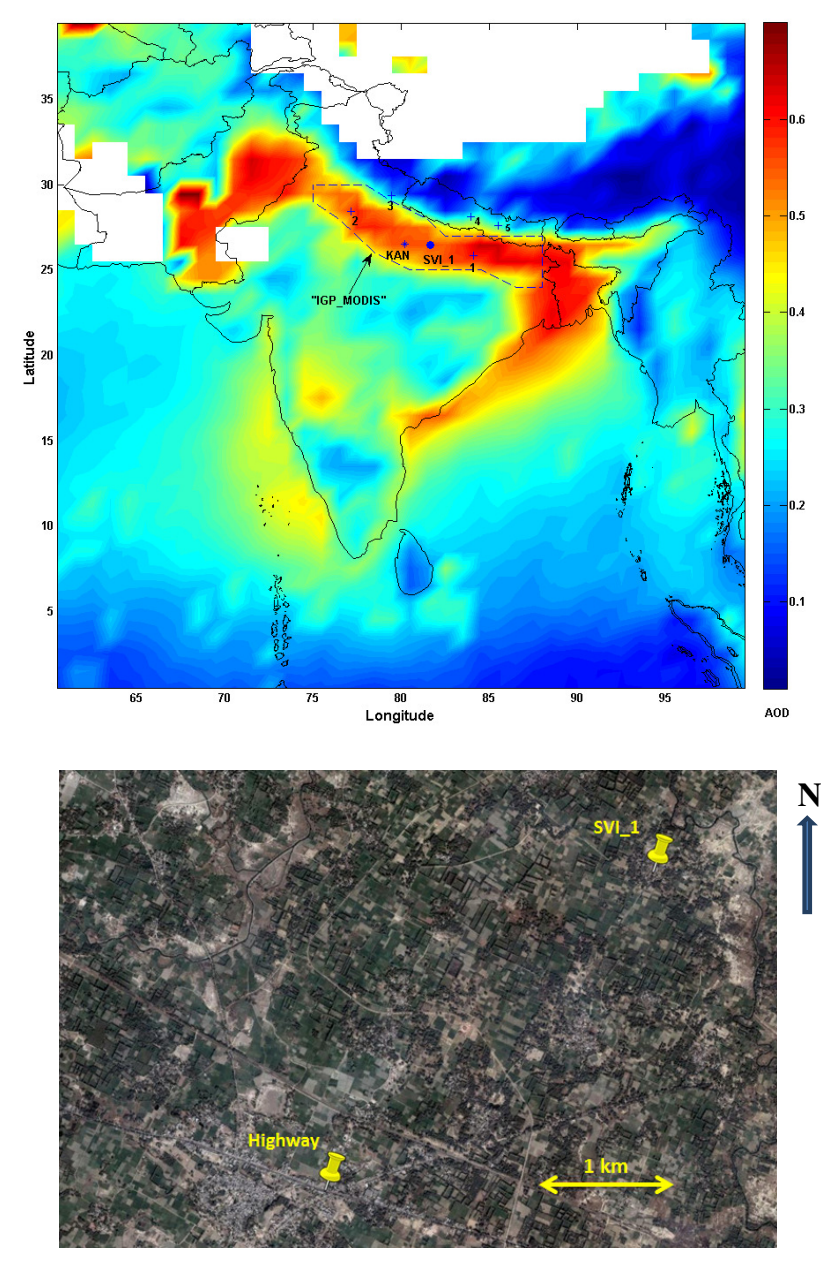

Fig. 1. (Above) MODIS TERRA mean aerosol optical depth (AOD) for the period 1 October 2009 to 14 April 2010 over India. SVI_1 (Surya village) represents our sampling location. KAN represents neighbouring urban (130 km away from SVI_1) AERONET site at Kanpur $\left(26.30^{\prime} \mathrm{N}, 80.31^{\prime} \mathrm{E}\right)$. Other AERONET sites in the IGP region are shown as 1 (Gandhi College; $25.52^{\prime} \mathrm{N}, 84.07^{\prime} \mathrm{E}$ ), 2 (Gual

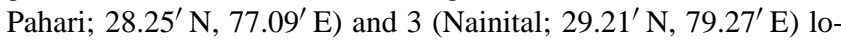
cated in India; 4 (Pokhara; 28.09 $\mathrm{N}, 83.58^{\prime} \mathrm{E}$ ) and 5 (Kathmandu University; $27.36^{\prime} \mathrm{N}, 85.32^{\prime} \mathrm{E}$ ) located in Nepal. Dashed line represents the "IGP_MODIS" region used for calculating regional mean AOD (using MODIS). (Below) Satellite view showing locations of our two sampling sites; SVI_1 and highway.

\section{Experimental description}

\subsection{Site description}

Project Surya's observational campaign was started on 15 October 2009 in a typical Indian rural village $\left(26^{\circ} \mathrm{N}, 81^{\circ} \mathrm{E}\right)$ located in the IGP region (Fig. 1). The Surya village (referred to as SVI_1 from hereafter) was nearly $3 \mathrm{~km}$ from a national highway, approximately $2 \mathrm{~km}$ from a state highway, and was located within $15 \mathrm{~km}$ radius of an industrial zone. The SVI_1 had around 485 households in seven close-by hamlets. We 
conducted experiments in the largest hamlet which consisted of around 200 households. Most of the households used biomass as cooking fuel. Outdoor fires (for relief during the cold winter) and occasional open burning of crop residue were the other major sources of biomass originated aerosol apart from cooking. Vehicular and industrial emissions were the fossil fuel related pollution sources in the region.

\subsection{Instrumentation}

Observations were classified as indoor and outdoor measurements. For indoor observations, concentration of real-time $\mathrm{BC}$ and elemental carbon (EC) were measured in the kitchen microenvironment in selected SVI_1 households. Real-time $\mathrm{BC}$ was measured using a single wavelength (880-nm) microAeth Model AE51 (Magee Scientific, Berkeley, CA). Three AE51 instruments (MA158, MA160, and MA165) were used for indoor BC measurement. The flow rate used for sampling was $50 \mathrm{ml} \mathrm{min}^{-1}$ with a time base of $1 \mathrm{~min}$. In addition, 24-h indoor integrated aerosol samples were collected on quartz filter using a novel cell phone based $\mathrm{BC}$ monitoring system (BC_CBM). These filter samples were subjected to EC/OC analysis using a thermal-optical EC/OC analyzer (Schauer et al., 2003). Details of indoor sampling and analysis using BC_CBM and AE51 were given in Ramanathan et al. (2011) and Rehman et al. (2011).

Outdoor measurements consisted of measuring real-time $\mathrm{BC}$ and aerosol scattering coefficient to understand the aerosol heating and cooling properties. For this purpose, we chose a sampling site at the center of the SVI_1 (denoted as VC site). We also measured BC at the North-East corner of the SVI_1 (denoted as NEV site) to understand aerosol spatial variability in the village. The distance between the NEV and VC sites was approximately $250 \mathrm{~m}$. At $\mathrm{NEV}$, real-time $\mathrm{BC}$ concentration measurements were started on 15 October 2009 using 7-wavelength Aethalometer Model AE42 (Magee Scientific, Berkeley, CA). At VC, real-time measurements of both $\mathrm{BC}$ and aerosol scattering coefficient were started on 1 November 2009; BC was measured using a 7-wavelength Aethalometer Model AE31 (Magee Scientific, Berkeley, CA). Aerosol scattering coefficient was measured using the single wavelength (550-nm) integrating nephelometer Model M9003 (ECOTECH). In addition, oneweek observations of $\mathrm{BC}$ and aerosol scattering coefficient were also conducted at the highway (nearest traffic junction from the SVI_1) from 19-27 November 2009 using the AE42 and the nephelometer to infer the fossil fuel contribution.

Both AE42 and AE31 were operated with a flow rate set at $21 \mathrm{~min}^{-1}$ and a measurement frequency of $2 \mathrm{~min}$. The nephelometer was operated at a sample flow of $51 \mathrm{~min}^{-1}$. The scattering response of the nephelometer was calibrated using $\mathrm{CO}_{2}$ as a span gas and filtered air as zeroing gas. The nephelometer has different illumination sensitivities for coarse and fine particles due to truncation of forward scattering; the instrument cannot detect forward scattered light between 0-7 degrees (Anderson and Ogren, 1998). However, we did not use any correction factor to account for angular truncation error of nephelometer data, since the illumination function in the ECOTECH nephelometer deviates significantly from other commercially available nephelometers (Müller et al., 2009). The instruments at both VC and NEV sites were deployed on the roof under the shade. The air sampling inlet was mounted at a height of $\sim 10 \mathrm{~m}$ above the ground; stainless steel tubing was used for sample intake. The inlet system was designed to prevent entry of raindrops or insects into the sample stream. BC measurements were tested with and without an inlet system to assess any particle loss. The slope and correlation coefficient of the comparison between BC measurement with and without inlet system (plot not shown here) were found as 0.99 and $R^{2}=0.78$, respectively, suggesting minimal particle loss.

\subsection{Data processing and validation}

AE31 and AE42 aethalometers measured attenuation of the light beam at seven different wavelengths $(370,470,520$, $590,660,880$ and $950 \mathrm{~nm}$ ) after being transmitted through aerosols which were continuously deposited on a quartz fiber filter. The aethalometer manufacturer (Magee Scientific) calibrated the instrument based on the assumption that the change in aerosol light attenuation coefficient $\left(\mathrm{m}^{-1}\right)$ is proportional to $\mathrm{BC}$ concentration $\left(\mathrm{g} \mathrm{m}^{-3}\right)$ through a constant called specific absorption cross section $\left(\mathrm{m}^{2} \mathrm{~g}^{-1}\right)$. The $880 \mathrm{~nm}$ channel is recommended by the manufacturer for BC measurement. However, due to aerosol-filter interactions (such as multiple light scattering effects within the filter and the "shadowing" effect due to filter loading), the aethalometer observed aerosol attenuation coefficient was larger than the actual air-borne aerosol absorption coefficient (Arnott et al., 2005; Schmid et al., 2006). Correction methods have been well documented in recent literature as a means by which to obtain the actual air-borne aerosol absorption coefficient from aethalometer aerosol attenuation coefficient data (Arnott et al., 2005; Schmid et al., 2006). The present data analysis followed the Schmid et al. (2006) method to derive air-borne aerosol light absorption coefficient at seven wavelengths from the aethalometer data. The derived aerosol light absorption coefficient was then converted to $\mathrm{BC}$ concentration through dividing it by a specific absorption cross section value. A wide range of values have been reported for specific absorption cross section (11.1 to $14.5 \mathrm{~m}^{2} \mathrm{~g}^{-1}$ at $670 \mathrm{~nm}$ ) for ambient BC aerosols depending upon the location in IGP region (Ram and Sarin, 2009). Considering specific absorption cross section inverse relation with wavelength, its values at $880 \mathrm{~nm}$ will be 8.6 to $11.2 \mathrm{~m}^{2} \mathrm{~g}^{-1}$. We used a middle value of $\sim 10 \mathrm{~m}^{2} \mathrm{~g}^{-1}$ for 880 -nm channel". We used the same approach for correcting data from AE51 instruments.

We first assessed the response of the aethalometer to pure biomass and fossil fuel combustion aerosol. For this purpose the AE31 instrument was operated for about an hour near a 


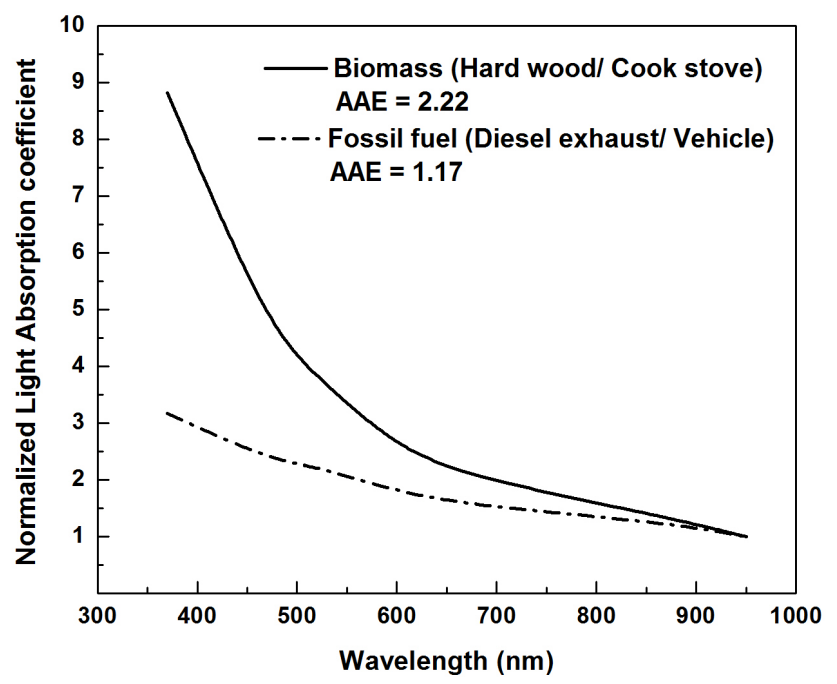

Fig. 2. Normalized light absorption coefficient of aerosol samples from biomass (hard wood in traditional mud cook stove) and fossil fuel (diesel) combustion measured using Aethalometer. AAE represents the absorption angstrom exponent.

biomass cook stove and a diesel vehicle exhaust. Figure 2 shows the wavelength dependence of the normalized light absorption coefficient for both the sources. The spectrally dependent aerosol absorption coefficient is given by a power law relationship $\sigma_{\lambda}=C \lambda^{-\mathrm{AAE}}$, where $\sigma_{\lambda}$ is the aerosol absorption coefficient at wavelength $(\lambda), C$ a constant, and AAE is the absorption Angstrom exponent (Kirchstetter et al., 2004). The biomass aerosol had higher absorption in the UV and visible regions compared to the fossil fuel aerosol. The AAE for the absorption coefficient was calculated by the negative slope of absorption vs. wavelength in a log-log plot (for wavelengths 370 to $950 \mathrm{~nm}$ ). Our results showed that the mean AAE value of biomass was observed as 2.2; while for fossil fuel the value was 1.17. The observed aethalometer response was in close agreement with earlier reported values (Bergstrom et al., 2007; Kirchstetter et al., 2004).

It is essential to assess the $\mathrm{BC}$ measurement precision among AE31, AE42, and three AE51 aethalometers for the same ambient air sample. Figure 3 shows the individual comparisons between the different aethalometers. All three AE51(MA158, MA160, MA165) were tested for precision in a rural household kitchen environments near a cook stove after being connected parallel to each other with a single inlet. Figure 3a-c shows comparisons between three AE51 instruments. BC measurements from all three AE51 agreed well with each other (slope ranging from 0.92 to 0.97 , and correlation coefficient $R^{2}$ ranging from 0.98 to 0.99 ). Figure $3 \mathrm{~d}-\mathrm{f}$ shows a comparison between $\mathrm{BC}$ measurements of co-located aethalometers AE 31, AE42 and AE51 (model MA160). The slope of inter-comparison ranged from 0.81 to 0.85 and $R^{2}$ ranged from 0.79 to 0.89 , indicating good consistency between the instruments.
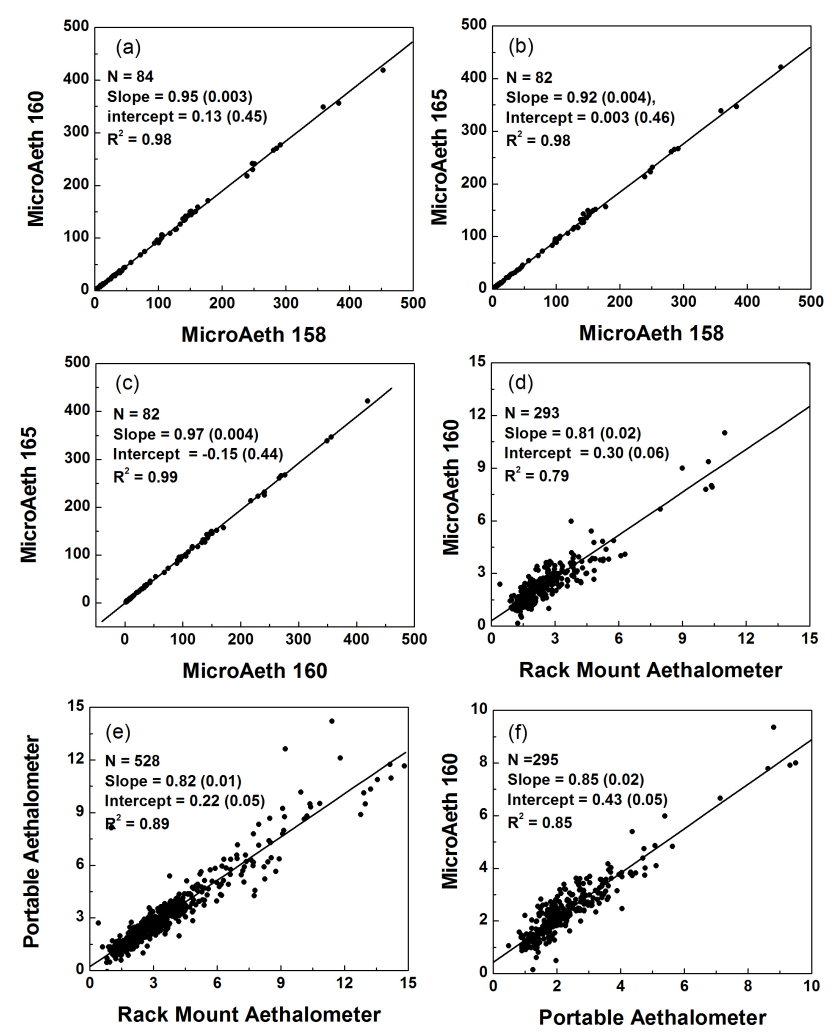

Fig. 3. Inter-comparison of $\mathrm{BC}$ measurements between three different models of Aethalometers (microAeth, Rack Mount and Portable) used in our study, standard errors for slope and Y offset at $95 \%$ confidence are given in brackets.

Finally we compared the ambient BC from AE31 (used as a representative of the aethalometer measurement) at $\mathrm{VC}$ with EC derived from the thermal-optical method. Figure 4 compares $\mathrm{BC}$ from AE31 with the EC from the thermaloptical method. The filters for the thermal-optical method was collected using the BC_CBM system running simultaneously with AE31. The slope and $\mathrm{R}^{2}$ of the comparison were found to be 0.89 and 0.52 , which were well within the range observed by many earlier studies. In our study BC was found to be $14 \%$ lower compared to EC. This could be partly attributed to the loss of $\mathrm{BC}$ data during frequent aethalometer tape advance, especially during peak $\mathrm{BC}$ concentration. On a typical observation day, $10-15 \%$ of $\mathrm{BC}$ data was lost due to tape advance.

\section{Results}

\subsection{Daily and monthly variation of $\mathrm{BC}$ concentrations in the SVI_1}

Figure 5 shows the daily and monthly mean variations of BC concentrations at the VC site from November 2009 to May 2010. Daily mean BC concentration at VC during the 


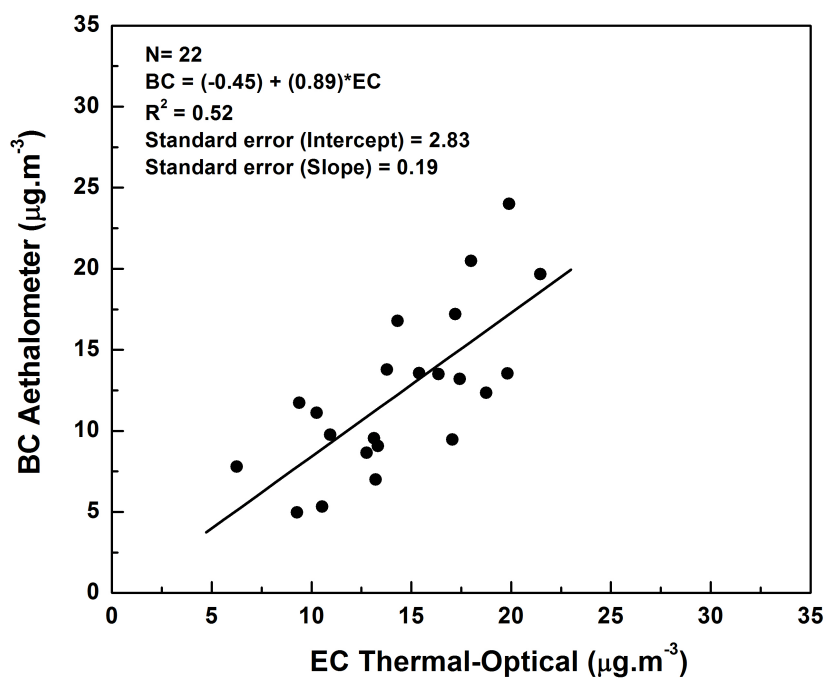

Fig. 4. Comparison of $\mathrm{BC}$ measurements (from Aethelometer) and EC measurements (from thermal-optical analyzer) at village center (VC) located in Surya Village (SVI_1).

study period varied from 3 to $56 \mu \mathrm{g} \mathrm{m}^{-3}$ with a mean value of $14.6 \pm 7.5 \mu \mathrm{g} \mathrm{m}^{-3}$. BC concentrations were found to be higher during the winter (or dry) season (December to February) compared to the pre-monsoon season (March to May). The highest monthly mean $\mathrm{BC}$ concentration at VC was observed in December $\left(22.5 \pm 5.2 \mu \mathrm{g} \mathrm{m}^{-3}\right)$, and after a gradual decrease to a lower value in March $\left(8.7 \pm 2.4 \mu \mathrm{g} \mathrm{m}^{-3}\right)$ the concentrations were found to increase again to $16 \pm 3.9$ $\mu \mathrm{g} \mathrm{m}^{-3}$ in April. High BC concentrations in winter may be attributed to an increase in the intensity of outdoor fires (for relief during the cold winter) as well as meteorological conditions such as low wind speeds and low level inversion. The effects of meteorological conditions are further explained in Sect. 5.1. The rise in ambient BC concentrations in April could be attributed to an increase in open burning activity (Beegum et al., 2009). This is further supported by the fire activity data from MODIS (plot not shown here) which showed that during the study period fire pixel count in the region $\left(29-24^{\circ} \mathrm{N}, 85-75^{\circ} \mathrm{E}\right)$ peaked in the month of April, 2010. Venkatraman et al. (2006) also reported that BC emission from forest fires peaked in March and the $\mathrm{BC}$ emission from crop residue burning peaked in May and October. The NEV site had a mean ambient BC concentration of $17.4 \pm 6.2$ $\mu \mathrm{g} \mathrm{m}^{-3}$ during 15 October 2009-30 April 2010. A comparison between BC measured at VC and NEV (plot not shown here) produced a slope of 0.96 and a $R^{2}$ of 0.64 indicating that there was not much spatial variation within the village.

\subsection{Diurnal variation of BC in the SVI_1}

Figure 6 shows the seasonal mean diurnal variation of ambient $\mathrm{BC}$ concentration at $\mathrm{VC}$. The diurnal variation of $\mathrm{BC}$ in all four seasons showed a similar trend; with twice daily

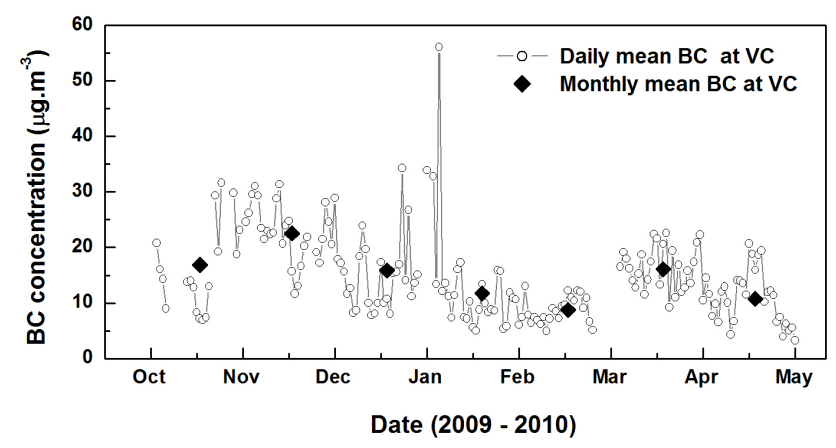

Fig. 5. Daily and monthly mean variation of $\mathrm{BC}$ concentrations at SVI_1 village centre (VC).

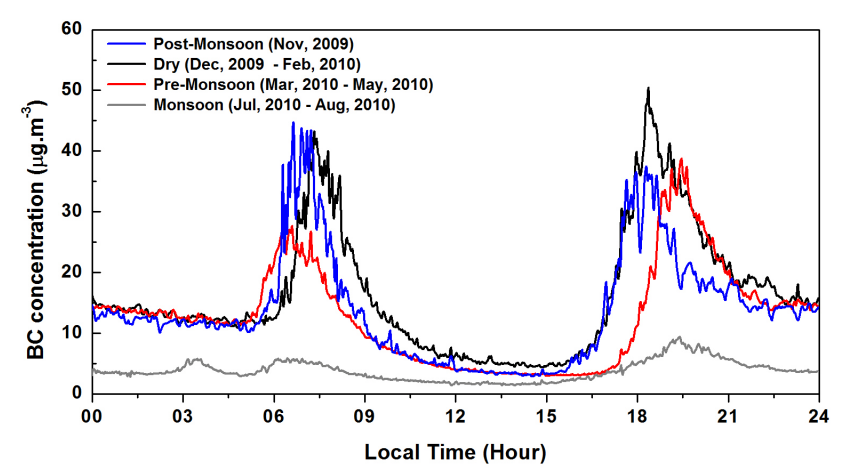

Fig. 6. Diurnal variation of seasonal mean $\mathrm{BC}$ concentration at SVI_1 village centre (VC).

maximum in $\mathrm{BC}$ concentration in the morning between 06:00 and 09:00 and in the evening between 17:00 and 20:00 local time. These times closely coincided with the morning and evening cooking hours in the village. BC concentrations decreased gradually from morning to noon, likely due to deepening of the boundary layer and convective pumping of pollution to the free troposphere. $\mathrm{BC}$ reached its minimum value between 12:00 and 15:00 h. A similar build of BC occurred during the evening cooking hours followed by a gradual decrease through the early morning hours. The morning and evening peak $\mathrm{BC}$ concentrations during the monsoon season were much lower compared to the other seasons (dry, premonsoon and post-monsoon).

\subsection{Comparison of SVI_1 BC with previous measurements in the region}

Over the past decade, there have been many observational campaigns and long-term monitoring studies for BC measurements in different parts of India covering urban, rural, coastal, marine and high altitude environments (see Table 1). Reported BC concentrations over Indian cities were found to be quite high when compared to cities in other parts of the world (Ganguly et al., 2006; Latha and Badarinath, 2005; 
Table 1. Comparison of SVI_1 BC concentration $\left(\mu \mathrm{g} \mathrm{m}^{-3}\right)$ with earlier reported BC concentration $\left(\mu \mathrm{g} \mathrm{m}^{-3}\right)$ at different locations in India.

\begin{tabular}{llllllll}
\hline Location & Site & Winter & Pre-Monsoon & Monsoon & Post-Monsoon & Year & Reference \\
\hline SVI_1 & Rural, IGP & 16.3 & 12.7 & 3.8 & 13.8 & $2009-10$ & Present \\
Gadanki & Rural & & 4 & 1 & & 2008 & Gadhavi and Jayaraman (2010) \\
Nepal, Godavari & Rural & $2.3-0.8$ & $1.7-1.1$ & $0.2-0.5$ & $0.5-0.5$ & 2006 & Stone et al. (2010) \\
Kharagpur & Urban, IGP & $9.3-7.5$ & $6.9-2.7$ & & & 2006 & Beegum et al. (2009) \\
Kanpur & Urban, IGP & $6-20$ & & & & 2004 & Tripati et al. (2005) \\
Agra & Urban, IGP & $17.4-10.5$ & & & & 2004 & Safai et al. (2008) \\
Delhi & Urban, IGP & $27-19$ & $12-8.1$ & & & 2006 & Beegum et al. (2009) \\
Ahmedabad & Urban & 11.6 & 3.9 & 2.1 & 10.9 & 2008 & Ramachandran and Kedia (2010) \\
Pune & Urban & 7.4 & 3.3 & 1.3 & 6 & 2005 & Safai et al. (2007) \\
Hyderabad & Urban & $21-25$ & $12-15$ & & & 2006 & Beegum et al. (2009) \\
Trivandrum, & Urban, Costal & $\sim 5$ & & & & $2000-01$ & Babu and Moorthy (2002) \\
Vishakhapatnam & Urban, Costal & 8 & 3.3 & 1.7 & 0.4 & $2005-06$ & Sreekanth et al. (2007) \\
Manora Peak & Hill station & 1.8 & 0.9 & 0.5 & 1.4 & $2005-08$ & Ram et al. (2010) \\
Mukteshwar & Hill station & $1.2-0.5$ & $1.4-0.9$ & $0.8-0.3$ & $0.8-0.7$ & $2005-07$ & Hyvärinen et al. (2009) \\
Nepal, NCOP & Hill station & 0.13 & 0.3 & 0.06 & 0.14 & $2006-07$ & Marinoni et al. (2010) \\
Port Blair & Marine & 2.6 & $1.8-1.3$ & & & 2006 & Beegum et al. (2009) \\
MCOH, Maldives & Marine & 0.7 & & 0.04 & & $2004-05$ & Corrigen et al. (2006) \\
Minicoy & Marine & 0.5 & $0.2-0.07$ & & & 2006 & Beegum et al. (2009) \\
\hline
\end{tabular}

Babu and Moorthy, 2002). The observed BC concentrations in India showed large spatial variations depending on the location (Table 1); mainland BC concentrations (especially urban centers and IGP region) were much higher than those at high altitude and island stations. Total aerosol and BC aerosol concentrations were 5-10 times higher over the IGP region compared with non-IGP locations (Nair et al., 2007; Beegum et al., 2009). The observed daily mean and diurnal variation of BC concentrations at SVI_1 were within the range of reported values in the region (Beegum et al., 2009).

\section{Characteristics of solar absorption by BC}

\subsection{Time series of aerosol scattering and absorption coefficient}

Figure 7a shows the daily mean variation of aerosol scattering and absorption coefficients at VC during the study period. Aerosol scattering coefficient showed an increasing trend from the post monsoon season to the winter season, before displaying a decreasing trend from winter towards the monsoon season. Aerosol absorption coefficient followed a similar trend to that of BC (Fig. 5) but unlike the scattering coefficient trend, it did not have a maximum during winter. The winter time peak in the scattering coefficient coincided with a corresponding peak in the relative humidity (daily mean RH shown in Fig. 7b), thus implying hygroscopic growth of the aerosol (Pan et al., 2009). Biomass burning, because of its combustion condition, emits significant fraction of volatile organics. Therefore freshly emitted BC particles, which have fractal-like structure, are covered by thin layer of non-absorbing condensed volatile organic.
The layer of non-absorbing coating (such as organics) on BC aerosol is known to enhance its absorption characteristics. However in the winter months, we found significant increase in the aerosol scattering coefficient values, even though the winter months are expected to have relatively more burning of biomass (mainly wood for relieve from cold weather). The likely reason could be the increase in the $\mathrm{RH}$ values during the winter months. With increase in the RH values, the radius or the size of the $\mathrm{BC}$ particles will grow because of water uptake and collapse of the fractal-like shape to more spherical shape due to surface tension of water. The relatively larger BC particle with thick coating of water vapor will scatter more light (Pereira et al., 2011) that will offset the enhance absorption due to condensed volatile organics.

The aerosol single scattering albedo (SSA), which is the ratio of the scattering to the extinction coefficient, is one of the important parameters which determine the impact of aerosols on radiative forcing. Figure $7 \mathrm{c}$ illustrates the daily mean variation of surface SSA at VC along with columnar SSA (from AERONET) at adjacent urban center Kanpur $\left(26.30^{\prime} \mathrm{N}, 80.31^{\prime} \mathrm{E}\right)$. Between January and March, VC and Kanpur SSA values were in a similar range with values ranging between 0.7 and 0.95 . However, during the rest of the year, VC SSA values were mostly less than 0.8 compared to Kanpur columnar SSA. When SSA falls below 0.9, aerosols significantly heat the atmosphere and reduce solar radiation at the surface, thus causing large impact on regional climate and the hydrological cycle (Ramanathan et al., 2001a; Krishnan and Ramanathan, 2002; Menon et al., 2002). 

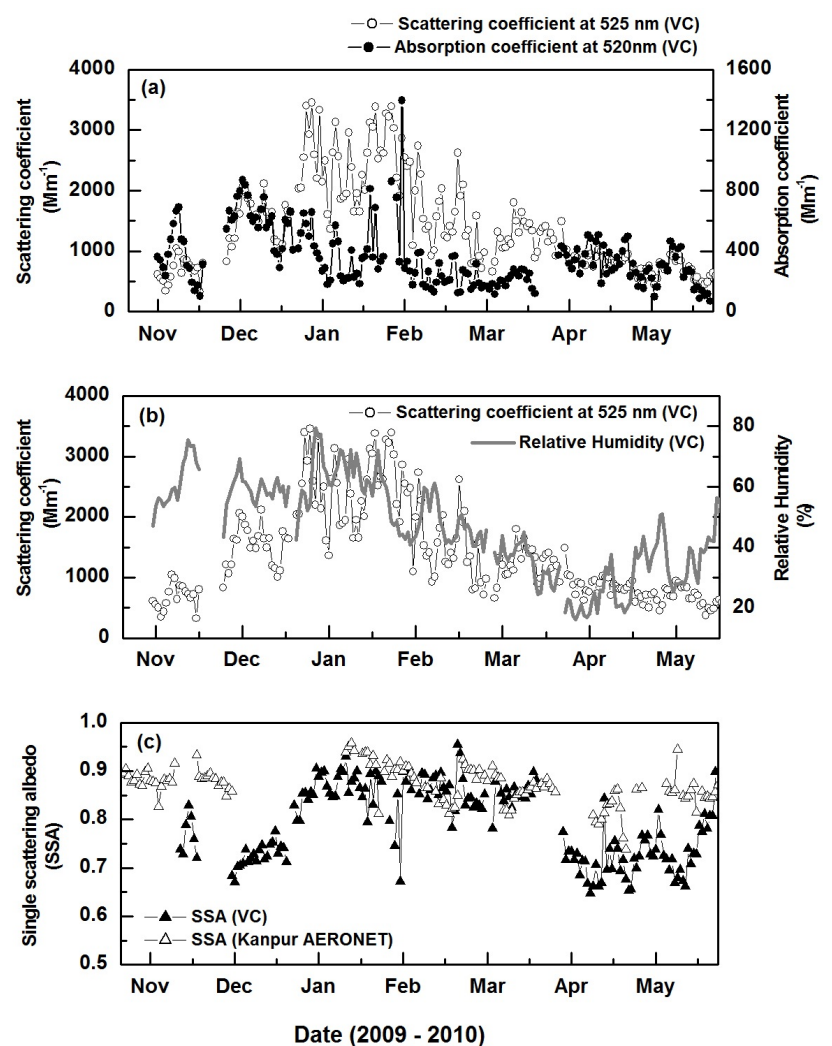

Fig. 7. (a) Daily variation of aerosol absorption coefficient and scattering coefficient from surface observation at SVI_1 village center (VC), (b) daily variation of scattering coefficient and relative humidity (RH) from surface observation at SVI_1 village center (VC), (c) daily variation of single scattering albedo (SSA) at SVI_1 village center (VC) and column measured SSA from AERONET site located in neighbouring urban centre, Kanpur.

Figure 8 shows the diurnal variation of aerosol absorption and scattering coefficient, and relative humidity along with SSA for VC and the near-by highway. The aerosol scattering and absorption coefficients showed a similar diurnal pattern at $\mathrm{VC}$ and the highway, with slightly higher values observed at the highway. SSA values were observed to be high in the afternoon time between 12:00 and 15:00 for both the VC and the highway locations. During noon time, secondary aerosol production through photochemical processes may increase scattering aerosols compare to absorbing aerosols, which may be reflected in the higher SSA (Yan et al., 2008). Furthermore, SSA showed a decreasing trend in the evening hours and increased towards night time. The absorbing aerosols (BC) are emitted directly from combustion sources (cook stoves, vehicles), whereas some of the scattering aerosols are formed via a gas to particle conversion process (Lyamani et al., 2010). This delay in the formation processes of absorbing and scattering aerosol and increase in $\mathrm{BC}$ emission from cook stoves and vehicles may cause the dip in SSA in the evening hours. Similar processes should
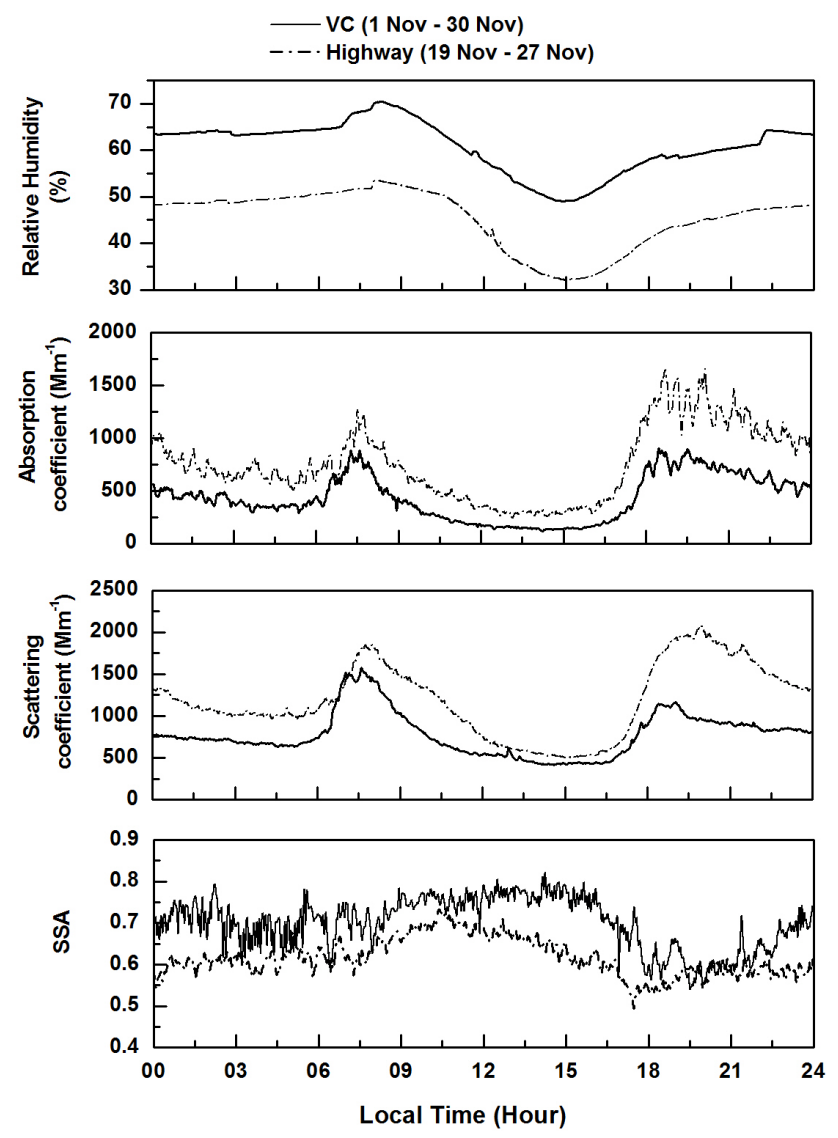

Fig. 8. Comparison of diurnal variation of relative humidity, absorption coefficient, scattering coefficient and single scattering albedo (SSA) at SVI_1 village center (VC) and highway (traffic junction).

also effect morning peak emission hours, however the SSA did not show any dip; a matter which requires further investigation.

\subsection{Absorption Angstrom exponent}

As previously demonstrated (Kirchstetter et al., 2004; Rizzo et al., 2011; Chakrabarty et al., 2010), the spectral dependence of light absorption can be used to distinguish between aerosols originating from fossil fuel and biomass fuel combustion. The presence of brown carbon (light absorbing OC mainly from biomass combustion) enhances the aerosol light absorption in the wavelength region $\lambda<600 \mathrm{~nm}$. Understanding the spectral dependence of aerosol absorption is important for climate studies.

Figure 9a and $\mathrm{b}$ show the normalized aerosol light absorption of aerosol at highway and the $\mathrm{VC}$ during cooking and non-cooking hours. The figure also shows the observed aethalometer response (from Sect. 2.3) to biomass (wood in cook stove) and fossil fuel (diesel) combustion aerosol, along with published (Kirchstetter et al., 2004) observations. A clearly distinct aerosol light absorption pattern can be seen 


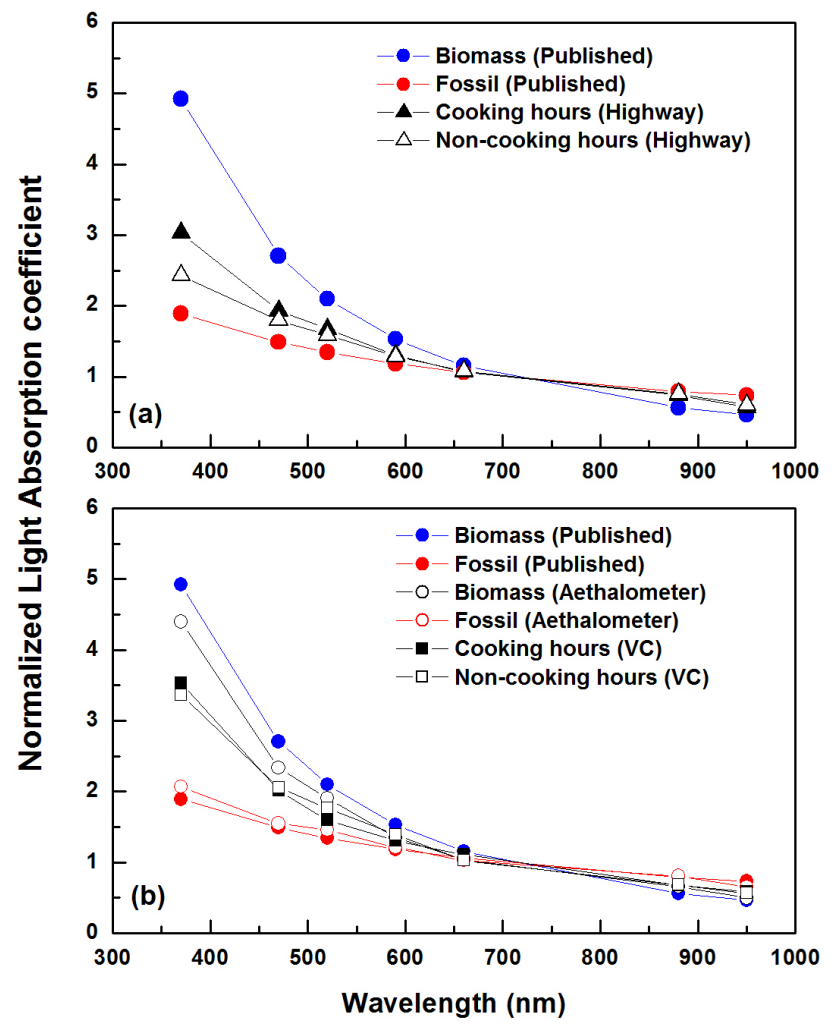

Fig. 9. Comparison of normalized light absorption coefficient of aerosol during cooking and non-cooking hours at (a) Highway and (b) SVI_1 village center (VC). Also show is earlier published (Kirchstetter et al., 2004) and the observed aethalometer response to biomass and fossil fuel combustion aerosols.

for biomass and fossil fuel sources of aerosol. Both published and observed Aethalometer response data indicated that the normalized aerosol light absorption at $370 \mathrm{~nm}$ was $\sim 5$ times higher compared to the $700 \mathrm{~nm}$ for biomass combustion sources and $\sim 2$ times higher for fossil fuel combustion sources. Aerosol light absorption falling in between the two extremes of biomass and fossil fuel absorption pattern is indicative of the combined effect of aerosols from the two sources. Normalized aerosol light absorption at both VC (Fig. 9b) and the highway (Fig. 9a) location indicated that the aerosol sources were influenced by both biomass and fossil fuel sources; with VC normalized aerosol light absorption falling closer to pure biomass absorption line which is indicative of higher contribution by biomass aerosol. Interestingly, at the highway, aerosol light absorption showed enhanced absorption at the shorter wavelength during cooking hours compared to non-cooking hours. This is indicative of the influence of biomass cooking activity on highway aerosol. This is not surprising since the highway is surrounded by villages. During non-cooking hours the normalized aerosol light absorption at highway was closer to pure fossil fuel absorption line indicating the dominance of fossil fuel (diesel) generated aerosol.

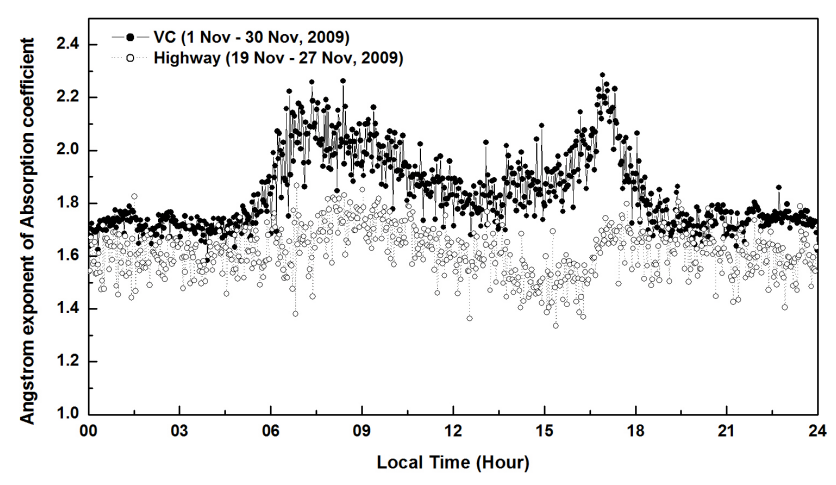

Fig. 10. Diurnal variation of Angstrom exponent of absorption coefficient at village center (VC) and highway.

Several studies have found that aerosols originating from fossil fuel combustion show weaker dependence on spectral light absorption, with the absorption Angstrom exponent (AAE) value close to 1 (Bergstrom et al., 2007; Kirchstetter et al., 2004). However for aerosol emitted from biomass burning, the values of the AAE have been reported between 1.5 and 3; a value of 2 is often considered as a mean (Bergstrom et al., 2007; Kirchstetter et al., 2004). An AAE value between 1 and 2 could be indicative of aerosol of mixed origin, that is, fossil and biomass fuel. The mean AAE values for the $\mathrm{VC}$ and the highway were found to be 1.81 and 1.61 , respectively. It is understandable that the lower value was observed at the highway since fossil fuel contribution was higher there compared to other locations. The higher value observed at the $\mathrm{VC}$ was due to a high contribution of aerosol from biomass combustion sources, as almost all households use biomass as cooking fuel. The AAE values at $\mathrm{VC}$ showed a similar diurnal pattern to BC (Fig. 10), with two prominent peaks - one in the morning hours of 06:0009:00 and the other during the evening hours of 17:00-20:00. BC peaks were dependent on sources and meteorology conditions, whereas the AAE peaks indicated relatively different contributions from sources during that time. Peak values of $\mathrm{AAE}$ at VC during cooking hours reached between 2.0 and 2.2 , suggesting that biomass contribution was most dominant during this period. The major biomass burning activities during this time were observed to be cooking and winter outdoor fires. The highway AAE showed slight diurnal variation with values in the range of 1.4-1.7.

\section{Local to regional scale linkages}

\subsection{Vertical variations and transport of aerosol}

The fundamental mechanism for local to regional scale transport of pollution is vertical transport (e.g. pumping by cumulus convection) from the surface layer to the free troposphere above, and from there it is carried by winds to other regions. 

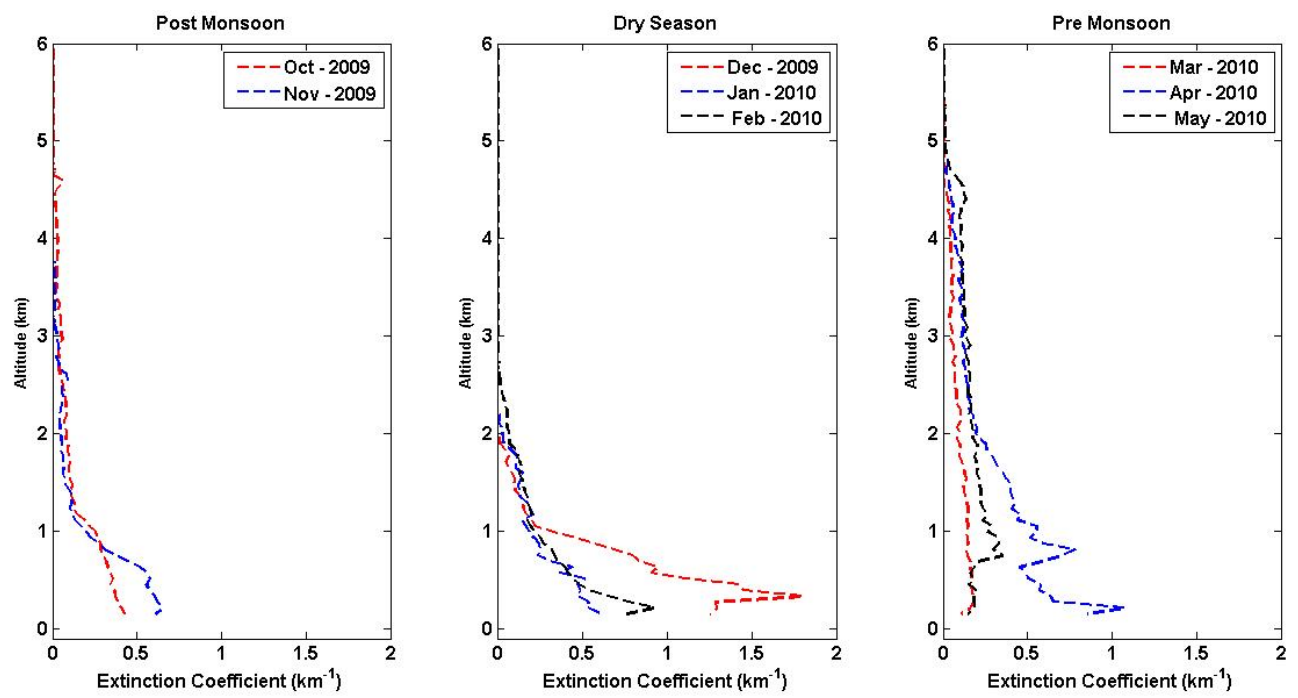

Fig. 11. Monthly mean LIDAR extinction profiles $(532 \mathrm{~nm})$ from CALIPSO for the grid $\left(26-27^{\circ} \mathrm{N}\right.$ and $\left.80-82^{\circ} \mathrm{E}\right)$ for post-monsoon, dry and pre-monsoon seasons, respectively. SVI_1 is located within this grid.

The Cloud-Aerosol Lidar and Infrared Pathfinder Satellite Observation (CALIPSO) satellite provides high-resolution vertical distribution of aerosol and clouds whilst also offering a unique opportunity to study vertical transport of aerosol. The CALIPSO lidar instrument known as CALIOP (Cloud-Aerosol Lidar with Orthogonal Polarization) measures the depolarized aerosol back-scattered light at wavelength $532 \mathrm{~nm}$. Figure 11 shows the monthly mean CALIOP LIDAR level-2 extinction profiles over the observation location $\left(26-27^{\circ} \mathrm{N}\right.$ and $\left.80-82^{\circ} \mathrm{E}\right)$.

During the monsoon season (June-September), air flow in the lower troposphere is predominantly Westerly over India, which brings a large influx of moist air from the Arabian Sea. During the post monsoon season (October-November) the Westerly flow weakens in the lower troposphere and transitions into Easterly flow. From the post-monsoon to the dry (winter) season (December-February), the daily mean surface temperatures gradually decrease, reaching minimum values during the dry season. Fair weather conditions with clear skies and dry conditions exist during the dry season. As shown in Fig. 11 for the post-monsoon season, the aerosols were mostly confined within $\sim 2 \mathrm{~km}$ from the surface with a maximum seasonal extinction coefficient value of $\sim 0.5 \mathrm{~km}^{-1}$ (observed during the month of November at $\sim 0.5 \mathrm{~km}$ altitude). Almost no aerosol layer was observed above $\sim 3 \mathrm{~km}$ during the post-monsoon season. The observed $\mathrm{BC}$ concentration at the surface was $13.8 \pm 7.6 \mu \mathrm{g} \mathrm{m}^{-3}$ in the post monsoon season. During the dry season, low level inversions lead to a shallower aerosol layer (compared to the pre-monsoon season) resulting in accumulation of pollutants near the surface. This is clearly seen in Fig. 11; the extinction coefficients reached their highest values of $\sim 1.7 \mathrm{~km}^{-1}$ at $\sim 0.5 \mathrm{~km}$ altitude during the month of December in the dry season. In addition, aerosol layers were not observed above $\sim 2 \mathrm{~km}$ and the containment of the pollution within a shallow boundary layer led to a build up of BC concentrations which reached a maximum of $16.3( \pm 8.8) \mu \mathrm{g} \mathrm{m}^{-3}$ in the winter. During the pre-monsoon season (March-May) the weather is very hot and dry, with a deep boundary layer and maximum daytime temperatures reaching as high as $45^{\circ} \mathrm{C}$. During this season, dust content in the atmosphere is high, whilst open burning activities such as forest fires and crop residue burning are common. The monthly mean extinction profiles indicate that the aerosol layer is transported as high as $\sim 5 \mathrm{~km}$ due to vertical mixing and convection, resulting in lower BC concentration $\left(12.7 \pm 5 \mu \mathrm{g} \mathrm{m}^{-3}\right)$ at the surface.

\subsection{Regional scale correlations}

Aerosol optical depth (AOD) is a measure of the columnar extinction of light due to aerosols, with higher AOD values indicative of higher aerosol loading in that column. The vast IGP region has higher AOD values than the rest of India during all seasons (Ramanathan and Ramana, 2005; Ramana et al., 2004; Chung et al., 2010). MODIS (Moderate-resolution Imaging Spectroradiometer) level-3 TERRA AOD data was used to quantify aerosol column content at SVI_1 and regional mean of IGP (denoted as "IGP_MODIS"). The region considered for IGP_MODIS is displayed as a dashed line in Fig. 1. Figure 12 illustrates the daily variation of AOD at SVI_1 (MODIS TERRA) and Kanpur (AERONET). MODIS TERRA has two prominent over pass time over the observational location, one during 05:00 GMT and other $\sim$ 17:00 GMT. Total of 118 daily mean AOD data points were available for inter-comparison study during 15 October to 14 April. The SVI_1 AOD showed a similar trend 


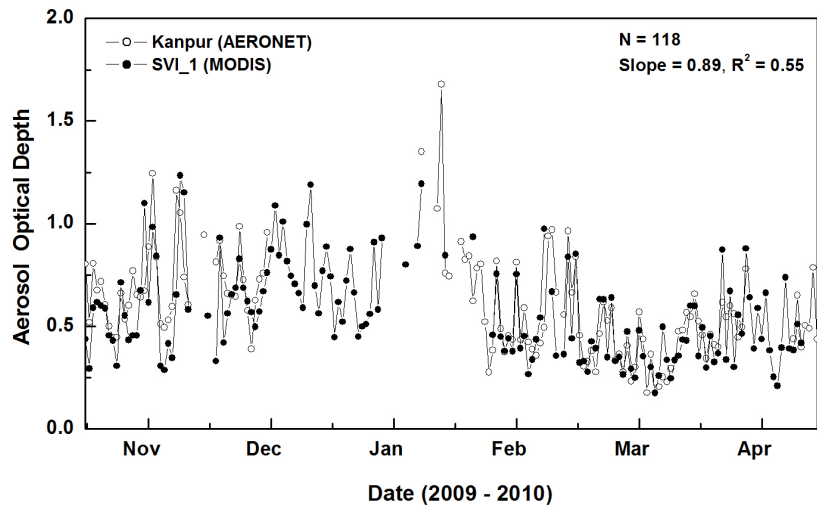

Fig. 12. Comparison of temporal variation of daily mean MODIS aerosol optical depth (AOD) at Surya Village (SVI_1) and AERONET measured column AOD at neighbouring urban centre (130 km away from SVI_1), Kanpur.

with neighbouring (130 km away from SVI_1) urban center Kanpur. Comparison between SVI_1 AOD and Kanpur AOD (plot not shown here) yielded a slope of 0.89 and $R^{2}$ of 0.55 . Seasonal AOD variations in the IGP region show two prominent peaks - during the winter (December-January) and the pre-monsoon period (March-May). The winter peak is attributed to biomass burning and anthropogenic activities, whereas the pre-monsoon peak is influenced by dust aerosol from the Western Thar Desert (Prasad et al., 2007). Aerosol during winter is found to be of a highly absorbing nature (Tripathi et al., 2005; Ganguly et al., 2009).

The NASA AERONET began a four-year intensive field campaign on April 2008, called TIGERZ (http://tigerz.gsfc. nasa.gov/). The aim was to measure aerosol microphysical and optical properties over India. We considered the means of six TIGERZ AERONET stations' (shown in Fig. 1) data in the IGP region (denoted as "IGP_AERONET"). This was done in order to study local and regional aerosol propagation, by inter-comparing aerosol column optical properties between Kanpur (local) vs. IGP_AERONET. Errors in AERONET SSA and AAOD were estimated to be high for lower AOD values and dependent on solar zenith angles (Dubovik et al., 2002). For this study, we considered level-1.5 data points as valid for AOD $675 \mathrm{~nm}>0.2$ and solar zenith angle between $45^{\circ}-75^{\circ}$ during November 2009-May 2010.

Figure 13a-f illustrates the comparison between local to regional scale AOD, SSA, AAOD, Angstrom exponent of the $\mathrm{AOD}(\mathrm{AE})$, and Angstrom exponent of AAOD $\left(\mathrm{AAE}_{\mathrm{c}}\right)$. MODIS AOD at SVI_1 was correlated with IGP_MODIS AOD with $R^{2}=0.72$ and slope $=1.09$ (Fig. 13a). Similarly, AERONET AOD at Kanpur (local scale) was correlated with IGP_AERONET AOD with $R^{2}=0.62$ and slope $=0.71$ (Fig. 13b). We observed a similar correlation between local (SVI_1) to IGP_MODIS AOD for individual months (Fig. 14). This indicated that the column aerosol content
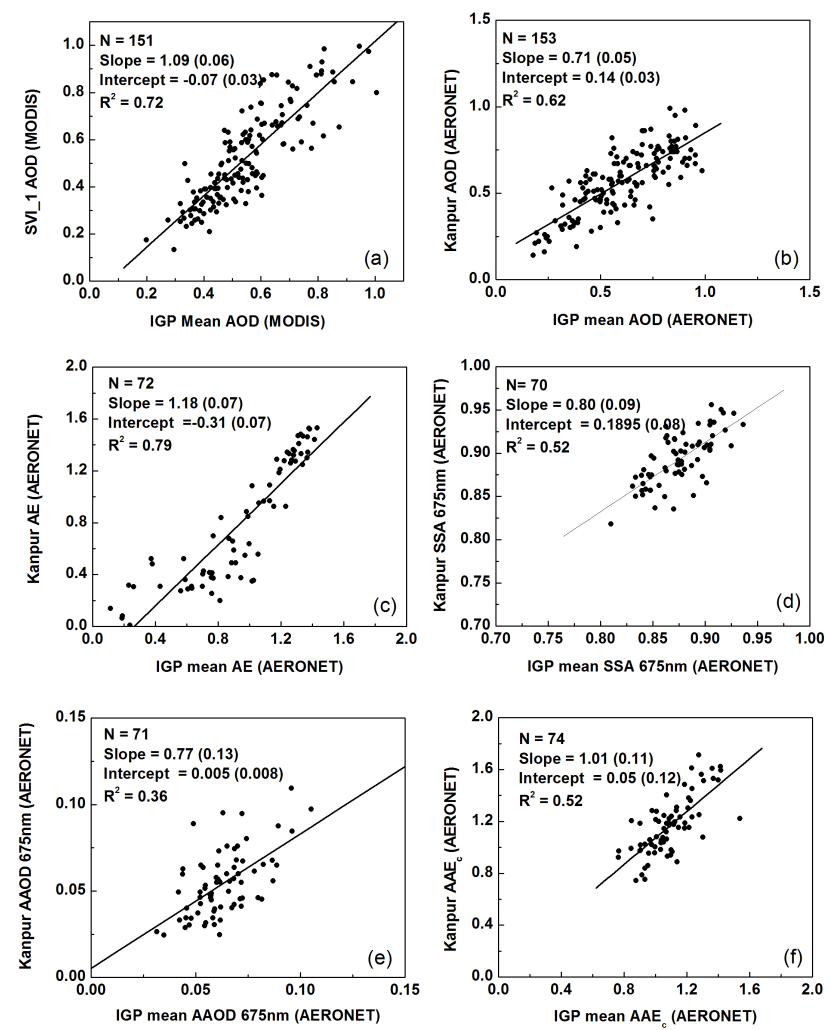

Fig. 13. Comparison of daily mean IGP_MODIS and IGP_AERONET to local (Kanpur and SVI_1) scale aerosol optical properties for the period November 2009 to May 2010. IGP_AERONET was calculated from the mean of six AERONET sites located in India and Nepal (see Fig. 1). The IGP_MODIS represents the mean of the AOD over the region shown as dashed line in Fig. 1. Standard errors for slope and Y offset at $95 \%$ confidence are given in brackets.

was homogeneously spread over the region during all seasons. The AE describe the spectral dependence of the aerosol optical depth on wavelength, through the equation: AOD $(\lambda)=\operatorname{AOD}\left(\lambda \_\mathrm{R}\right)\left(\lambda / \lambda \_\mathrm{R}\right)^{-\mathrm{AE}}$, where $\lambda$ is wavelength and $\lambda \_R$ is a reference wavelength. The AE is a useful quantity to assess the particle size of atmospheric aerosols, ranging from 2 for fine-mode pollution aerosols (diameter of $100 \mathrm{~nm}$ or less; referred to as fine mode) to values less than 0.5 for larger dust particles (few microns or larger; referred to as coarse mode). The AE was calculated by the negative slope of AOD vs. wavelength in a log-log plot (for wavelengths 437 to $1020 \mathrm{~nm}$ ). Local scale AE correlated with IGP_AERONET AE with $R^{2}=0.79$ and slope $=1.18$ (Fig. 13c), indicating that particle dominance - either fine or coarse - is identical to the regional scale. The local scale SSA was correlated with the IGP_AERONET SSA with $R^{2}=0.52$ and slope $=0.80$ (Fig. 13d), indicating that the relative contribution of scattering and absorbing aerosols has a similar fraction at the regional and local scale. Similar to the AE for AOD, we 

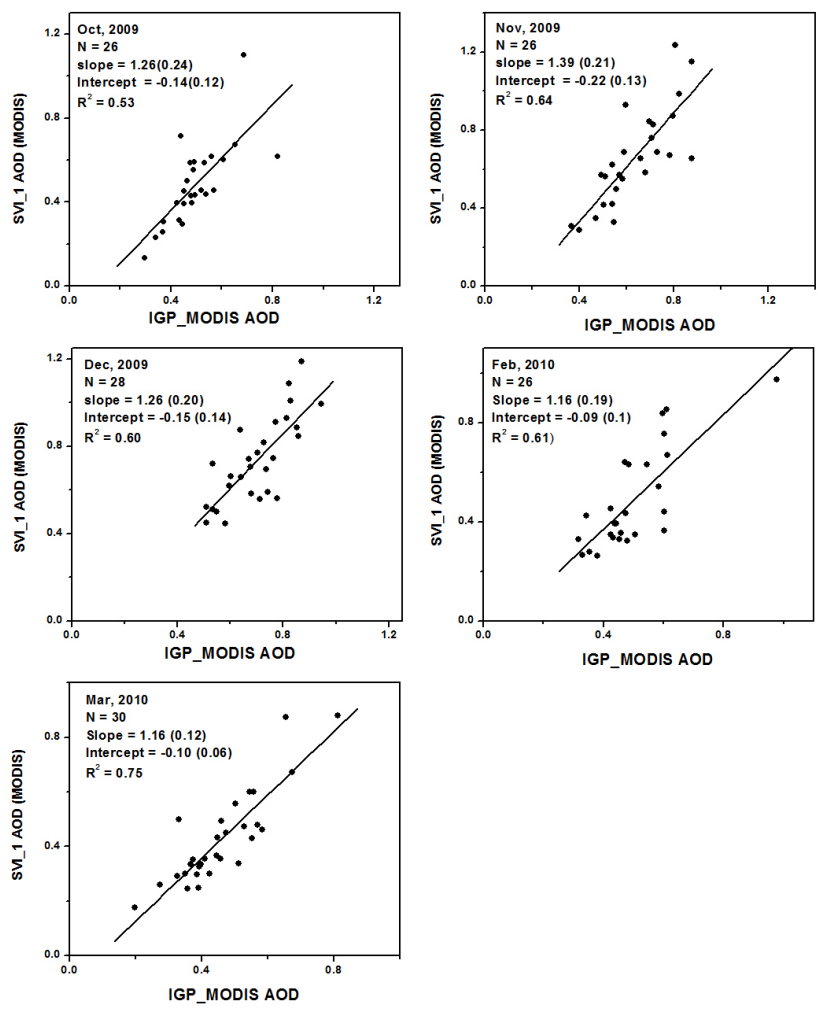

Fig. 14. Comparison of daily mean IGP_MODIS to local (SVI_1) scale MODIS aerosol optical depth (AOD) during different months. The IGP _MODIS represents the mean of the AOD over the region shown as dashed line in Fig. 1. Standard errors for slope and Y offset at $95 \%$ confidence are given in brackets.

can define AAEc for absorption optical depth. Larger AAE $(>2)$ is indicative of dust and organics which absorb strongly at shorter wavelengths $(<500 \mathrm{~nm})$, while AAEc $<1$ for BC. $\mathrm{AAE}_{\mathrm{c}}$ is observed to be near 3 for dust aerosols, about 1 for urban and industrial aerosols, and greater than 1 for biomass aerosols (Bergstrom et al., 2007; Russell et al., 2010). The local scale $\mathrm{AAE}_{\mathrm{c}}$ correlated with IGP_AERONET $\mathrm{AAE}_{\mathrm{c}}$ with $R^{2}=0.52$ and slope $=1.01$ (Fig. 13f), indicating that local to regional sources of observing aerosols are similar.

The observed AE of the IGP_AERONET was in the range of 0.1-1.6 indicating varying aerosol compositions, including dust domination to fine particles from biomass, urban and industrial sources. Particularly, during April-May 2010, $\mathrm{AE}$ was in the range of $0.1-0.8$ due to the large influence of dust aerosols, perhaps due to soil erosion or dust transport from the desert regions of western India (Fig. 15). Prasad et al. (2007) reported similar AE values during April-June over the IGP region with $\mathrm{AE}<0.2$ for a high dust event. The wavelength-dependence of the absorption of mineral dust depends on its composition, primarily hematite and certain clays. The $\mathrm{AAE}_{\mathrm{c}}$ of Saharan dust particles was in the range of 1-2 (Collaud Coen et al., 2004). The results of this study showed few data points with $\mathrm{AE}<0.2$ and $\mathrm{AAE}_{\mathrm{c}}>1$, indi-

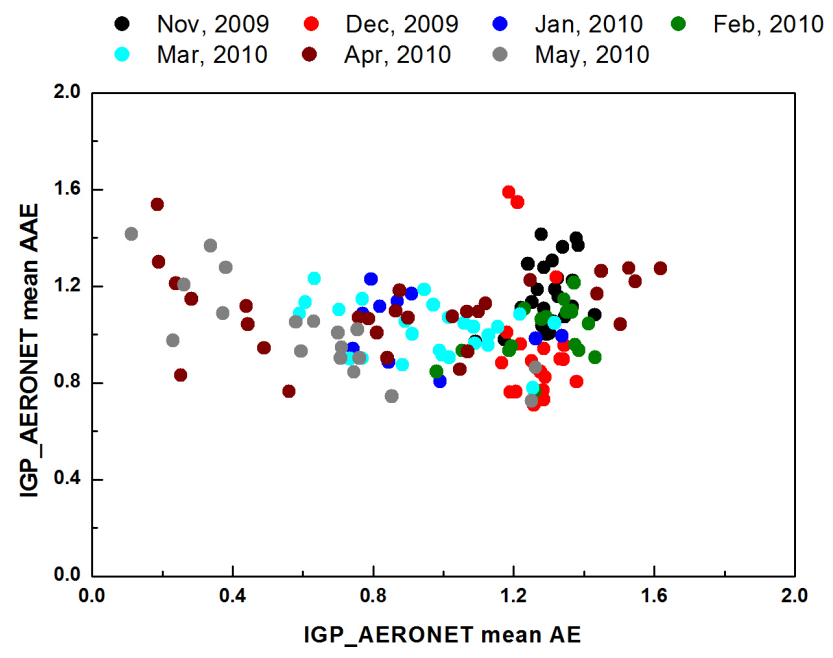

Fig. 15. Scatter plot of IGP_AERONET daily mean Angstrom exponent of AOD (AE) and daily mean Angstrom exponent of AAOD (AAE) for the IGP region. IGP_AERONET was calculated from the mean of six AERONET sites located in India and Nepal (see Fig. 1).

cating that occasionally IGP has regionally influenced dust transport. The high occurrence of $\mathrm{AE}>1$ and $\mathrm{AAE}_{\mathrm{c}}>1$ values suggested that the IGP region is mainly influenced by urban and biomass sources (Fig. 15).

\subsection{Regional scale atmospheric radiative forcing}

The Indian Ocean Experiment (INDOEX) documented for the first time (Ramanathan et al., 2001a) the haze-induced reduction in surface solar radiation and large atmospheric absorption at the regional scale as well as its importance in the hydrological cycle. Regionally, the absorbing haze reduced surface solar radiation by an amount comparable to $50 \%$ of the total ocean heat flux, and nearly doubled the lower tropospheric solar heating (Ramanathan et al., 2001) over the Indian Ocean during December to April. The hazeinduced reduction in surface solar radiation (surface forcing at $-23 \mathrm{Wm}^{-2}$ ) was 3 times larger than the reflected solar radiation at TOA (TOA forcing at $-7 \mathrm{Wm}^{-2}$ ) for clear skies and was a consequence of large atmospheric absorption (Ramanathan et al., 2001). However, the haze over the Indian Ocean is a layer of pollutants and particles from natural and anthropogenic sources which are transported from nearby continental land regions (Lawrence and Lelieveld, 2010). To quantify haze influence on regional and local climate, several observational studies were conducted over mainland regions. During such observations a seasonal and diurnal average reduction in surface solar radiation of approximately $32 \pm 5 \mathrm{Wm}^{-2}$ was observed over the IGP, using data collected over Kathmandu, Nepal, for a three-year mean (20012003 ) in the months of October to May (Ramanathan and Ramana, 2005). 

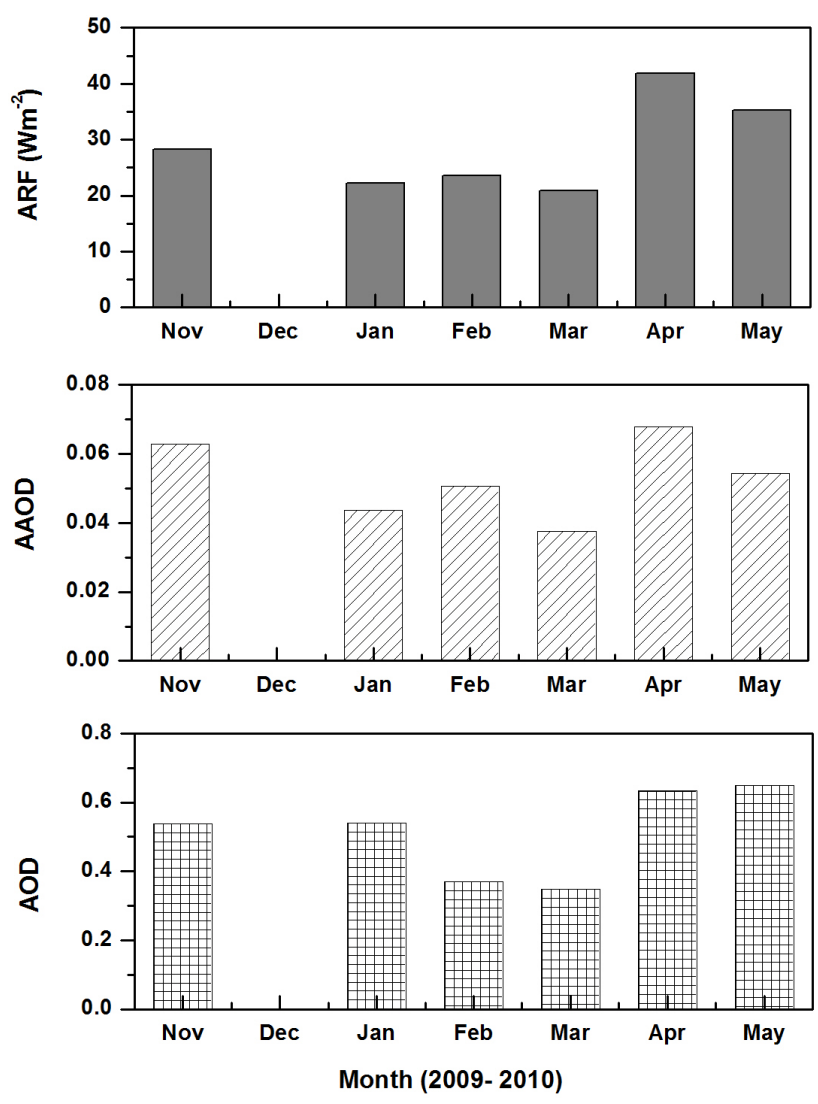

Fig. 16. Monthly mean aerosol optical depth (AOD), absorption aerosol optical depth (AAOD) and aerosol atmospheric radiative forcing (ARF) in the broadband region over Kanpur.

To quantify clear sky atmospheric aerosol radiative forcing in the IGP region, cloud-screened monthly mean Kanpur AERONET measured spectral AOD, spectral SSA, column water vapor, ozone, monthly CALIPSO extinction profiles and solar zenith angle were used as inputs to the Monte Carlo Aerosol Cloud Radiation (MACR) model. The MACR is a photon transport radiative transfer algorithm described by Podgorny et al. (2000). Several case studies have shown that MACR calculation are consistent with observations (Ramanathan et al., 2001a; Ramanathan et al., 2007; Ramana and Ramanathan, 2006). The observed monthly mean of $674 \mathrm{~nm}$ AOD was in the range of $0.35-0.65$, with a maximum of $\sim 0.65$ during April and May 2010 and a minimum of $\sim 0.35$ in March 2010 (Fig. 16). The SSA reached a minimum of $\sim 0.83$ at $674 \mathrm{~nm}$ in April 2010 (Fig. 16). The ground bas and satellite data were used to estimate the forcing efficiency defined as: change in the radiative energy budget due to a unit change in AOD. Calculated clear sky atmospheric aerosol forcing efficiencies were between $+41 \mathrm{Wm}^{-2}$ and $+66 \mathrm{Wm}^{-2}$, SSA at 0.92 to 0.83 at $670 \mathrm{~nm}$ wavelength, respectively (Fig. 16). Maximum forcing efficiencies were observed in April. Clear-sky atmospheric aerosol forcing was in the range of $+22 \mathrm{Wm}^{-2}$ to $+42 \mathrm{Wm}^{-2}$ with a mean of $+29 \mathrm{Wm}^{-2}$ (Fig. 16). The present study estimated that atmospheric aerosol forcing values were within the range of values reported by Day and Tripathi (2008) and Ramana et al. (2004) for the IGP region.

\section{Conclusions}

Ambient BC concentrations at the Project Surya village were in the range of 3.2-56 $\mu \mathrm{g} \mathrm{m}^{-3}$, about an order of magnitude larger than $\mathrm{BC}$ values in most polluted cities in developed countries of the world. The BC concentration reached peak values during winter, and gradually decreased towards the pre-monsoon period of March to May. Rural BC concentrations were well within the limits of observed urban BC in India. The diurnal variation of ambient outdoor $\mathrm{BC}$ suggested that $\mathrm{BC}$ emissions from cook stoves are a major source of ambient BC. This agrees with Rehman et al. (2011) results from aerosol absorption properties and $\mathrm{EC} / \mathrm{OC}$ fraction. The observed Angstrom exponent of the absorption coefficient (AAE) for SVI_1 was greater than 1.6 in all four seasons, suggesting a significant biomass contribution. The SSA was in the 0.7-0.9 range at the surface, indicative of highly absorbing aerosols. The estimated mean aerosol atmospheric forcing was observed at $29 \mathrm{Wm}^{-2}$. Statistically significant strong correlations between the village-scale values of AOD and SSA and the IGP basin-scale AOD and SSAs suggest that the village level data collected in this study can be used to infer regional scale effects of cook stove emissions, particularly for the dry season. Furthermore, the strong correlation between surface and column aerosol optical properties during the dry season implies that surface measurements are a valuable way to infer the column radiative forcing of cook stove emissions.

\section{Appendix A}

\section{List of abbreviations and acronyms}

Abbreviations/ Meaning

Acronyms

\begin{tabular}{ll}
\hline AAE & $\begin{array}{l}\text { Absorption angstrom exponent } \\
\text { Angstrom exponent of absorption } \\
\text { AAEc }\end{array}$ \\
aerosol optical depth \\
AAOD & $\begin{array}{l}\text { Absorption aerosol optical depth } \\
\text { Atmospheric brown clouds }\end{array}$ \\
AE & $\begin{array}{l}\text { Angstrom exponent of the aerosol opti- } \\
\text { cal depth }\end{array}$ \\
AE42 & Aethalometer model AE42 \\
AE31 & Aethalometer model AE31 \\
AE51 & microAeth model AE51 \\
AERONET & Aerosol robotic network
\end{tabular}




\begin{tabular}{|c|c|}
\hline AOD & Aerosol optical depth \\
\hline $\mathrm{BC}$ & Black carbon \\
\hline BC_CBM & Cell phone based $\mathrm{BC}$ monitoring system \\
\hline CALIPSO & $\begin{array}{l}\text { Cloud-Aerosol Lidar and Infrared } \\
\text { Pathfinder Satellite Observation }\end{array}$ \\
\hline CALIOP & $\begin{array}{l}\text { Cloud-Aerosol Lidar with Orthogonal } \\
\text { Polarization }\end{array}$ \\
\hline $\mathrm{CO} 2$ & Carbon dioxide \\
\hline EC & Elemental carbon \\
\hline IGP & Indo-Gangetic Plains \\
\hline INDOEX & Indian Ocean Experiment \\
\hline LIDAR & Light Detection And Ranging \\
\hline MACR & Monte Carlo Aerosol Cloud Radiation \\
\hline MODIS & $\begin{array}{l}\text { Moderate-resolution Imaging Spectro- } \\
\text { radiometer }\end{array}$ \\
\hline NASA & $\begin{array}{l}\text { National Aeronautics and Space Ad- } \\
\text { ministration }\end{array}$ \\
\hline NEV & North-East corner of the Surya village \\
\hline $\mathrm{OC}$ & Organic carbon \\
\hline RH & Relative humidity \\
\hline SSA & Single scattering albedo \\
\hline SVI_1 & Surya village \\
\hline TOA & Top-of-the-atmosphere \\
\hline UV & Ultraviolet \\
\hline $\mathrm{VC}$ & Center of the Surya village \\
\hline$\sigma$ & Absorption coefficient \\
\hline$\lambda$ & Wavelength \\
\hline
\end{tabular}

Acknowledgements. The authors wish to acknowledge private donors (E. Frieman, and D. Zaelke), the National Science Foundation (Grant AGS-1016496), the Swedish International Development Agency (through the United Nations Environment Programme, UNEP), The Vetlesen and the Alderson Foundations (through the Scripps Institution of Oceanography) for funding Project Surya. The authors thank UNEP for sponsoring Project Surya. Special thanks are extended to all individuals and organizations that have provided the data used in this study. The CALIPSO data were obtained via the NASA Langley Research Center website (http://www-calipso.larc.nasa.gov/). The MODIS data were obtained via the NASA Goddard Space Flight Center website (http://modis.gsfc.nasa.gov/). The authors also thank AERONET staff and data collection, calibration and processing. AERONET data was obtained via NASA AERONET website (http://aeronet.gsfc.nasa.gov/new_web/index.html).

Edited by: T. Kirchstetter

\section{References}

Anderson, T. L. and Ogren, J. A.: Determining aerosol radiative properties using the TSI 3563 integrating nephelometer, Aerosol Sci. Technol., 29, 57-69, 1998.

Andreae, M. O. and Gelencsér, A.: Black carbon or brown carbon? The nature of light-absorbing carbonaceous aerosols, Atmos. Chem. Phys., 6, 3131-3148, doi:10.5194/acp-6-3131-2006, 2006.
Arnott, W., Hamasha, K., Moosmüller, H., Sheridan, P. J., and Ogren, J. A.: Towards aerosol light-absorption measurements with a 7-wavelength aethalometer: Evaluation with a photoacoustic instrument and 3-wavelength nephelometer, Aerosol Sci Tech., 39, 17-29, 2005.

Babu, S. S. and Moorthy, K. K.: Aerosol black carbon over tropical coastal station in India, Geophys. Res. Lett., 29, 2098, doi:10.1029/2002GL015662, 2002.

Beegum, G. N., Moorthy, K. K., Babu, S. S., Sathhesh, S., Vinoj, V., Badarinath, K., Safai, P., Devara, P., Singh, S., Vinod, Dumka, U., and Pant, P.: Spatial distribution of aerosol black carbon over India during pre-monsoon season, Atmos. Environ., 43, 10711078, 2009.

Bergstrom, R. W., Pilewskie, P., Russell, P. B., Redemann, J., Bond, T. C., Quinn, P. K., and Sierau, B.: Spectral absorption properties of atmospheric aerosols, Atmos. Chem. Phys., 7, 5937-5943, doi:10.5194/acp-7-5937-2007, 2007.

Chakrabarty, R. K., Moosmüller, H., Chen, L.-W. A., Lewis, K., Arnott, W. P., Mazzoleni, C., Dubey, M. K., Wold, C. E., Hao, W. M., and Kreidenweis, S. M.: Brown carbon in tar balls from smoldering biomass combustion, Atmos. Chem. Phys., 10, 6363-6370, doi:10.5194/acp-10-6363-2010, 2010.

Chung, C. E., Ramanathan, V., Carmichael, G., Kulkarni, S., Tang, Y., Adhikary, B., Leung, L. R., and Qian, Y.: Anthropogenic aerosol radiative forcing in Asia derived from regional models with atmospheric and aerosol data assimilation, Atmos. Chem. Phys., 10, 6007-6024, doi:10.5194/acp-10-6007-2010, 2010.

Collaud Coen, M., Weingartner, E., Schaub, D., Hueglin, C., Corrigan, C., Henning, S., Schwikowski, M., and Baltensperger, U.: Saharan dust events at the Jungfraujoch: detection by wavelength dependence of the single scattering albedo and first climatology analysis, Atmos. Chem. Phys., 4, 2465-2480, doi:10.5194/acp4-2465-2004, 2004.

Corrigan C. E., Ramanathan, V., and Schauer, J. J.: Impact of monsoon transitions on the physical and optical properties of aerosols, J. Geophys. Res., 111, D18208, doi:10.1029/2005JD006370, 2006.

Dey, S. and Tripathi, S. N.: Aerosol direct radiative effects over Kanpur in the Indo-Gangetic basin, northern India: Long-term (2001-2005) observations and implications to regional climate, J. Geophys. Res., 113, D04212, doi:10.1029/2007JD009029, 2008.

Dubovik, O., Holben, B., Eck, T. F., Smirnov, A., Kaufman, Y. J., King, M. D., Tanre', D., and Slutsker, I.: Variability of absorption and optical properties of key aerosol types observed in worldwide locations, J. Atmos. Sci., 59, 590-608, 2002.

Flanner, M. G., Zender, C. S., Hess, P. G., Mahowald, N. M., Painter, T. H., Ramanathan, V., and Rasch, P. J.: Springtime warming and reduced snow cover from carbonaceous particles, Atmos. Chem. Phys., 9, 2481-2497, doi:10.5194/acp-9-24812009, 2009.

Gadhavi, H. and Jayaraman, A.: Absorbing aerosols: contribution of biomass burning and implications for radiative forcing, Ann. Geophys., 28, 103-111, doi:10.5194/angeo-28-103-2010, 2010.

Ganguly, D., Jayaraman, A., Rajesh, T. A., and Gadhavi, H.: Wintertime aerosol properties during foggy and nonfoggy days over urban center Delhi and their implications for shortwave radiative forcing, J. Geophys. Res., 111, D15217, doi:10.1029/2005JD007029, 2006. 
Ganguly, D., Ginoux,P., Ramaswamy,V., Winker,D.M., Holben, B. N., and Tripathi, S.N.: Retrieving the composition and concentration of aerosols over the Indo-Gangetic basin using CALIOP and AERONET data, Geophys. Res. Lett., 36, L13806, doi:10.1029/2009GL038315, 2009.

Hyvärinen, A.-P., Lihavainen, H., Komppula, M., Sharma, V. P., Kerminen, V.-M., Panwar, T. S., and Viisanen, Y.: Continuous measurements of optical properties of atmospheric aerosols in Mukteshwar, Northern India, J. Geophys. Res., 114, D08207, doi:10.1029/2008JD011489, 2009.

Jacobson, M. Z.: Short-term effects of controlling fossil-fuel soot, biofuel soot and gases, and methane on climate, arctic ice, and air pollution health, J. Geophys. Res., 115, D14209, doi:10.1029/2009JD013795, 2010.

Kar, A., Praveen, P. S., Suresh, R., Rehman, I. H., Singh, L., Singh, V. K., Ahmed, T., Burney, J., and Ramanathan, V.: Real time assessment of black carbon pollution in rural households due to cooking in traditional and improved biomass stoves, Environ. Sci. Technol., submitted, 2011.

Kirchstetter, T. W., Novakov, T., and Hobbs, P. V.: Evidence that the spectral dependence of light absorption by aerosols is affected by organic carbon, J. Geophys. Res., 109, D21208, doi:10.1029/2004JD004999, 2004.

Krishnan, R. and Ramanathan, V.: Evidence of surface cooling from absorbing aerosols, Geophys. Res. Lett., 29, 1340, doi:10.1029/2002GL014687, 2002.

Lawrence, M. G. and Lelieveld, J.: Atmospheric pollutant outflow from southern Asia: a review, Atmos. Chem. Phys., 10, 1101711096, doi:10.5194/acp-10-11017-2010, 2010.

Latha, K. M. and Badarinath, K. V. S.: Seasonal variations of black carbon aerosols and total aerosol mass concentrations over urban environment in India, Atmos. Environ., 39, 4129-4141, 2005.

Lau, K. M., Ramanathan, V., Wu, G. X., Li, Z., Tsay, S. C., Hsu, C., Sikka, R., Holben, B., Lu, D., Tartari, G., Chin, M., Koudelova, P., Chen, H., Ma, Y., Huang, J., Taniguchi K., and Zhang, R.: The Joint Aerosol-Monsoon Experiment, B. Am. Meteorol. Soc., 89, $1-15,2008$

Lyamani, H., Olmo, F. J., and Alados-Arboledas, L.: Physical and optical properties of aerosols over an urban location in Spain: seasonal and diurnal variability, Atmos. Chem. Phys., 10, 239254, doi:10.5194/acp-10-239-2010, 2010.

Marinoni, A., Cristofanelli, P., Laj, P., Duchi, R., Calzolari, F., Decesari, S., Sellegri, K., Vuillermoz, E., Verza, G. P., Villani, P., and Bonasoni, P.: Aerosol mass and black carbon concentrations, a two year record at NCO-P (5079 m, Southern Himalayas), Atmos. Chem. Phys., 10, 8551-8562, doi:10.5194/acp-10-85512010, 2010.

Menon, S., Hansen, J., Nazarenko, L., and Luo, Y.: Climate effects of black carbon aerosols in China and India, Science, 297, 22502253, 2002.

Menon, S., Koch, D., Beig, G., Sahu, S., Fasullo, J., and Orlikowski, D.: Black carbon aerosols and the third polar ice cap, Atmos. Chem. Phys., 10, 4559-4571, doi:10.5194/acp-10-4559-2010, 2010.

Molina, M., Zaelke, D., Sarma, K. M., Andersen, S. O., Ramanathan, V., and Kaniaru, D.: Reducing abrupt climate change risk using the Montreal Protocol and other regulatory actions to complement cuts in $\mathrm{CO} 2$ emissions, P. Natl. Acad. Sci., doi:10.1073/pnas.0902568106, 2009.
Müller, T., Nowak, A., Wiedensohler, A., Sheridan, P., Laborde, M., Covert, D. S., Marinoni, A., Imre, K., Henzing, B., Roger, J.-C., Martins dos Santos, S., Wilhelm, R., Wang, Y.-Q., and de Leeuw, G.: Angular illumination and truncation of three different integrating nephelometers: implications for empirical, sizebased corrections, Aerosol Sci. Tech., 43, 581-586, 2009.

Nair, V. S., Moorthy, K. K., Alappattu, D. P., Kunhikrishnan, P. K., George, S., Nair, P. R., Babu, S. S, Abish, B., Satheesh, S. K., Tripathi, S. N., Niranjan, K., Madhavan, B. L., Srikant, V., Dutt, C. B. S., Badarinath, K. V. S., and Reddy, R. R.: Wintertime aerosol characteristics over the Indo-Gangetic Plain (IGP): Impacts of local boundary layer processes and long-range transport, J. Geophys. Res., 112, D13205, doi:10.1029/2006JD008099, 2007.

Pan, X. L., Yan, P., Tang, J., Ma, J. Z., Wang, Z. F., Gbaguidi, A., and Sun, Y. L.: Observational study of influence of aerosol hygroscopic growth on scattering coefficient over rural area near Beijing mega-city, Atmos. Chem. Phys., 9, 7519-7530, doi:10.5194/acp-9-7519-2009, 2009.

Pereira, S. N., Wagner, F., and Silva, A. M.: Seven years of measurements of aerosol scattering properties, near the surface, in the southwestern Iberia Peninsula, Atmos. Chem. Phys., 11, 17-29, doi:10.5194/acp-11-17-2011, 2011

Pettus, A.: "Agricultural Fires and Arctic Climate Change", Clean Air Task Force, May, 2009.

Podgorny, I. A., Conant, W., Ramanathan, V., and Satheesh, S. K.: Aerosol modulation of atmospheric and surface solar heating over the tropical indian ocean, Tellus, 52B, 947-958, 2000.

Prasad, A. K., Singh, S., Chauhan, S. S., Srivastava, M. K., Singh, R. P., and Singh, R.: Aerosol radiative forcing over the IndoGangetic plains during major dust storms, Atmos. Environ., 41, 6289-6301, doi:10.1016/j.atmosenv.2007.03.060, 2007.

Ram, K. and Sarin, M. M.: absorption coefficient and site-specific mass absorption efficiency of elemental carbon in aerosols over urban, rural, and high-altitude sites in India, Environ. Sci. Technol., 43, 8233-8239, 2009.

Ram, K., Sarin, M. M., and Hegde, P.: Long-term record of aerosol optical properties and chemical composition from a high-altitude site (Manora Peak) in Central Himalaya, Atmos. Chem. Phys., 10, 11791-11803, doi:10.5194/acp-10-11791-2010, 2010.

Ramachandran, S. and Kedia, S.: Black carbon aerosols over an urban region: Radiative forcing and climate impact, J. Geophys. Res., 115, D10202, doi:10.1029/2009JD013560, 2010.

Ramana, M. V. and Ramanathan, V.: Abrupt transition from natural to anthropogenic aerosol radiative forcing: Observations at the ABC-Maldives Climate Observatory, J. Geophys. Res., 111, D20207, doi:10.1029/2006JD007063, 2006.

Ramana, M. V., Ramanathan, V., Podgorny, I. A., Pradhan, B. B., and Shrestha, B.: The direct observations of large aerosol radiative forcing in the Himalayan Region, Geophy. Res. Lett., 31, L05111, doi:10.1029/2003GL018824, 2004.

Ramanathan, V. and Balakrishnan, K.: Project Surya: Reduction of air pollution and global warming by cooking with renewable sources, White paper, available at: http://www.projectsurya.org/ storage/Surya-WhitePaper.pdf, 2007.

Ramanathan, V. and Carmichael, G.: Global and regional climate changes due to black carbon, Nature Geosci., 1, 221-227, 2008.

Ramanathan, V. and Ramana, M. V.: Persistent, widespread, and strongly absorbing haze over the Himalayan foothills and the 
Indo-Gangetic Plains, Pure Appl. Geophys., 162, 1609-1626, 2005.

Ramanathan, V. and Wallack, J.: The other climate changes, why black carbon also matters, Foreign Affairs, Sept/Oct 2009, 105113, 2009.

Ramanathan, V. and Xu, Y.: The Copenhagen Accord for limiting global warming: Criteria, constraints, and available avenues, $\mathrm{P}$. Natl. Acad. Sci., 107, 8055-8062, 2010.

Ramanathan, V., Crutzen, P. J., Lelieveld, J., Mitra, A. P., Althausen, D., Anderson, J., Andreae, M. O., Cantrell, W., Cass, G. R., Chung, C. E., Clarke, A. D., Coakley, J. A., Collins, W. D., Conant, W. C., Dulac, F., Heintzenberg, J., Heymsfield, A. J., Holben, B., Howell, S., Hudson, J., Jayaraman, A., Kiehl, J. T., Krishnamurti, T. N., Lubin, D., McFarquhar, G., Novakov, T., Ogren, J. A., Podgorny, I. A., Prather, K., Priestley, K., Prospero, J. M., Quinn, P. K., Rajeev, K., Rasch, P., Rupert, S., Sadourny, R., Satheesh, S. K., Shaw, G. E., Sheridan, P., and Valero, F. P. J.: The Indian Ocean Experiment: An integrated analysis of the climate forcing and effects of the Great Indo-Asian Haze, J. Geophys. Res., 106, 28371-28398, 2001a.

Ramanathan, V., Crutzen, P. J., Kiehl, J. T., and Rosenfeld, D.: Aerosols, Climate, and the Hydrological Cycle, Science, 294, 2119-2124, 2001b.

Ramanathan, N., Lukac, M., Ahmed, T., Kar, A., Siva, P., Honles, T., Leong, I., Rehman, I. H., Schauer, J., and Ramanathan, V.: A cellphone based system for large-scale monitoring of black carbon, Atmos. Environ., 45, 4481-4487, 2011.

Ramanathan, V., Ramana, M. V., Roberts, G., Kim, D., Corrigan, C. E., Chung, C. E., and Winker, D.: Warming trends in Asia amplified by brown cloud solar absorption, Nature, 448, 575578, doi:10.1038/nature06019, 2007.

Reddy, M. S. and Boucher, O.: Climate impact of black carbon emitted from energy consumption in the world's regions, Geophys. Res. Lett., 34, L11802, doi:10.1029/2006GL028904, 2007.

Rehman, I. H., Ahmed, T., Praveen, P. S., Kar, A., and Ramanathan, V.: Black carbon emissions from biomass and fossil fuels in rural India, Atmos. Chem. Phys., 11, 7289-7299, doi:10.5194/acp-117289-2011, 2011.

Rizzo, L. V., Correia, A. L., Artaxo, P., Procópio, A. S., and Andreae, M. O.: Spectral dependence of aerosol light absorption over the Amazon Basin, Atmos. Chem. Phys., 11, 8899-8912, doi:10.5194/acp-11-8899-2011, 2011.

Russell, P. B., Bergstrom, R. W., Shinozuka, Y., Clarke, A. D., DeCarlo, P. F., Jimenez, J. L., Livingston, J. M., Redemann, J., Dubovik, O., and Strawa, A.: Absorption Angstrom Exponent in AERONET and related data as an indicator of aerosol composition, Atmos. Chem. Phys., 10, 1155-1169, doi:10.5194/acp10-1155-2010, 2010.

Safai, P. D., Kewat, S., Praveen, P. S., Rao, P. S. P., Momin, G. A., Ali, K., and Devara, P. C. S.: Seasonal Variation of black carbon aerosol over tropical urban city of Pune,India, Atmos. Environ., 41, 2699-2709, 2007.

Safai, P. D., Kewat, S., Pandithurai, G., Praveen, P. S., Ali, K., Tiwari, S., Rao, P. S. P., Budhawant, K. B., Saha, S. K., and Devara, P. C. S.: Aerosol characteristics during winter fog at Agra, North India, J. Atmos. Chem., 61, 101-118, 2008.
Sauvain, J. J., Vu Duc, T., and Guillemin, M.: Exposure to polycyclic aromatic compounds and health risk assessment for diesel exposed workers, Int Arch. Occup. Environ. Health., 76, 443455, 2003.

Schauer, J. J., Mader, B. T., DeMinter, J. T., Heidemann, G., Bae, M. S., Seinfeld, J. H., Flagan, R, C., Cary, R. A., Smith, D., Huebert, B. J., Bertram, T., Howell, S., Kline, J. T., Quinn, P., Bates, T., Turpin, B., Lim, H. J., Yu, J. Z., Yang, H., and Keywood, M. D.: ACE-Asia intercomparison of a thermal-optical method for the determination of particle-phase organic and elemental carbon, Environ. Sci. Technol., 37, 993-1001, 2003.

Schmid, O., Artaxo, P., Arnott, W. P., Chand, D., Gatti, L. V., Frank, G. P., Hoffer, A., Schnaiter, M., and Andreae, M. O.: Spectral light absorption by ambient aerosols influenced by biomass burning in the Amazon Basin. I: Comparison and field calibration of absorption measurement techniques, Atmos. Chem. Phys., 6, 3443-3462, doi:10.5194/acp-6-3443-2006, 2006.

Schwarze, P. E., Ovrevik, J., and Lag, M.: Particulate matter properties and health effects: consistency of epidemiological and toxicological studies, Human and Experimental Toxicology, 25, 559-579, 2006.

Smith, K. R., Mehta, S., and Feuz M.: Indoor air pollution from household use of solid fuels, in: Comparative quantification of health risks: global and regional burden of disease attributable to selected major risk factors, edited by: Ezzati M., Geneva, World Health Organization, 2004.

Sreekanth, V., Niranjan, K., and Madhavan, B. L.: Radiative forcing of black carbon over eastern India, Geophys. Res. Lett., 34, L17818, doi:10.1029/2007GL030377, 2007.

Stone, E. A., Schauer, J. J., Pradhan, B. B., Dangol, P. M., Habib, G., Venkataraman, C., and Ramanathan, V.: Characterization of emissions from South Asian biofuels and application to source apportionment of carbonaceous aerosol in the Himalayas, J. Geophys. Res., 115, D06301, doi:10.1029/2009JD011881, 2010.

Tripathi, S. N., Dey, S., Tare, V., and Satheesh, S. K.: Aerosol black carbon radiative forcing at an industrial city in northern India, Geophys. Res. Lett., 32, L08802, doi:10.1029/2005GL022515, 2005.

Venkataraman, C., Habib, G., Eiguren-Fernandez, A., Miguel, A. H., and Friedlander, S. K.: Residential biofuels in South Asia: carbonaceous aerosol emissions and climate impacts, Science, 307, 1454-1456, 2005.

Venkataraman, C., Habib, G., Kadamba, D., Shrivastava, M., Leon, J.-F., Crouzille, B., Boucher, O., and Streets, D. G.: Emissions from open biomass burning in India: integrating the inventory approach with higher solution Moderate Resolution Imaging Spectroradiometer (MODIS) active fire and land count data, Global Biogeochem. Cy., 20, GB2013, doi:10.1029/2005GB002547, 2006.

Yan, P., Tang, J., Huang, J., Mao, J. T., Zhou, X.J., Liu, Q., Wang, Z. F., and Zhou, H. G.: The measurement of aerosol optical properties at a rural site in Northern China, Atmos. Chem. Phys., 8, 2229-2242, doi:10.5194/acp-8-2229-2008, 2008. 